\title{
Structural framework of a major intracontinental orogenic termination zone: the easternmost Tien Shan, China
}

\author{
DICKSON CUNNINGHAM ${ }^{1}$, LEWIS A. OWEN ${ }^{2}$, LARRY W. SNEE ${ }^{3} \&$ LI JILIANG ${ }^{4}$ \\ ${ }^{1}$ Orogenic Processes Group, Department of Geology, University of Leicester, Leicester, UK (e-mail: wdc2@le.ac.uk) \\ ${ }^{2}$ University of California, Riverside, Department of Earth Sciences, Riverside, CA, USA \\ ${ }^{3}$ Denver Argon Geochronology Laboratory, US Geological Survey, Denver, CO, USA \\ ${ }^{4}$ Institute of Geology, Chinese Academy of Sciences, Beijing, P.R. China
}

\begin{abstract}
The Barkol Tagh and Karlik Tagh ranges of the easternmost Tien Shan are a natural laboratory for studying the fault architecture of an active termination zone of a major intracontinental mountain range. Barkol and Karlik Tagh and lesser ranges to the north are bounded by active thrust faults that locally deform Quaternary sediments. Major thrusts in Karlik Tagh connect along strike to the east with the left-lateral GobiTien Shan Fault System in SW Mongolia. From a Mongolian perspective, Karlik Tagh represents a large restraining bend for this regional strike-slip fault system, and the entire system of thrusts and strike-slip faults in the Karlik Tagh region defines a horsetail splay fault geometry. Regionally, there appears to be a kinematic transition from thrust-dominated deformation in the central Tien Shan to left-lateral transpressional deformation in the easternmost Tien Shan. This transition correlates with a general eastward decrease in mountain belt width and average elevation and a change in the angular relationship between the NNE-directed maximum horizontal stress in the region and the pre-existing basement structural grain, which is northwesterly in the central Tien Shan (orthogonal to $\mathrm{SH}_{\max }$ ) but more east-west in the eastern Tien Shan (acute angular relationship with $\mathrm{SH}_{\max }$ ). Ar-Ar ages indicate that major range-bounding thrusts in Barkol and Karlik Tagh are latest Permian-Triassic ductile thrust zones that underwent brittle reactivation in the Late Cenozoic. It is estimated that the modern mountain ranges of the extreme easternmost Tien Shan could have been constructed by only $10-15 \mathrm{~km}$ of Late Cenozoic horizontal shortening.
\end{abstract}

Keywords: Tien Shan, Cenozoic, tectonics, intracontinental belts.

In this paper we examine the structural architecture of the Barkol Tagh and Karlik Tagh ranges at the extreme eastern termination of the Tien Shan in western China (Fig. 1). Our study is based on field observations and satellite image analysis and includes new $\mathrm{Ar}-\mathrm{Ar}$ age constraints for the timing of thrust deformation. The easternmost Tien Shan region provides a natural laboratory for studying the active termination zone of a major intracontinental mountain range and the relationship between fault kinematics and orogenesis. These are important topics for workers interested in processes of along-strike propagation of mountain belts and the link between topography and kinematic regime. Late Cenozoic uplift of the Tien Shan is widely regarded as a distant effect of the Indo-Eurasia collision (Molnar \& Tapponnier 1975; Tapponnier \& Molnar 1979; Tapponnier et al. 1982; Cobbold \& Davy 1988) and thus the Tien Shan is an ideal region for studying the geological controls on active mountain building within continental interiors. Important questions exist concerning the range's crustal architecture, history of structural reactivation, distribution of modern tectonic activity, partitioning of strain within the orogen, and its overall role in the Phanerozoic continental assembly of central Asia.

The Tien Shan is seismically active throughout its length (Ni 1978; Nelson et al. 1987). It is dominated by thrusting on approximately east-west faults, right-lateral strike-slip events on NW-SE faults, and left-lateral faulting on ENE faults (Tapponnier \& Molnar 1979). These relationships suggest an overall north-south shortening strain derived from collisional stresses from the south (Tapponnier \& Molnar 1979; Cobbold \& Davy 1988). The eastern end of the Tien Shan consists of relatively narrow (50-100 km wide) but high ranges named Barkol Tagh and Karlik Tagh (maximum elevation $4928 \mathrm{~m}$ ), and several smaller parallel ranges that terminate in western China near the Mongolian border (Fig. 1). Sharply defined mountain fronts visible on digital topographic images (Fig. 1) or satellite views (Fig. 2) suggest that active faults bound many range fronts.

Cenozoic uplift of the Tien Shan is believed to have been initiated in the late Oligocene or early Miocene (c. $25 \mathrm{Ma}$, Allen et al. 1991; Avouac et al. 1993; Hendrix et al. 1994; Sobel \& Dumitru 1997), considerably later than initial collision and subsequent uplift at $c$. 60-50 Ma in the Himalayas-Karakorum and Pamirs to the south (Searle 1996). The extent to which uplift of the Tien Shan was diachronous or instantaneous along its $>2000 \mathrm{~km}$ length is unclear although the western Tien Shan has accommodated considerably more shortening than the eastern end (c. $10 \mathrm{~km}$ per degrees west gradient; Avouac et al. 1993; Burchfiel et al. 1999). Sedimentological data from basins to the north and south of the central and eastern Tien Shan indicate that the range has been a positive physiographical feature since the Triassic (Hendrix et al. 1992; Hendrix 2000; Greene et al. 2001). Fission-track and structural data from transects across the central Chinese Tien Shan indicate that the range has been repeatedly uplifted and structurally reactivated since original basement terrane amalgamation in the late Palaeozoic (Windley et al. 1990; Dumitru et al. 2001). Cenozoic exhumation of the Chinese Tien Shan is generally $<3 \mathrm{~km}$ except in some areas of the marginal thrust belts, suggesting that the modern range topography is at least partly inherited from older Mesozoic mountain 


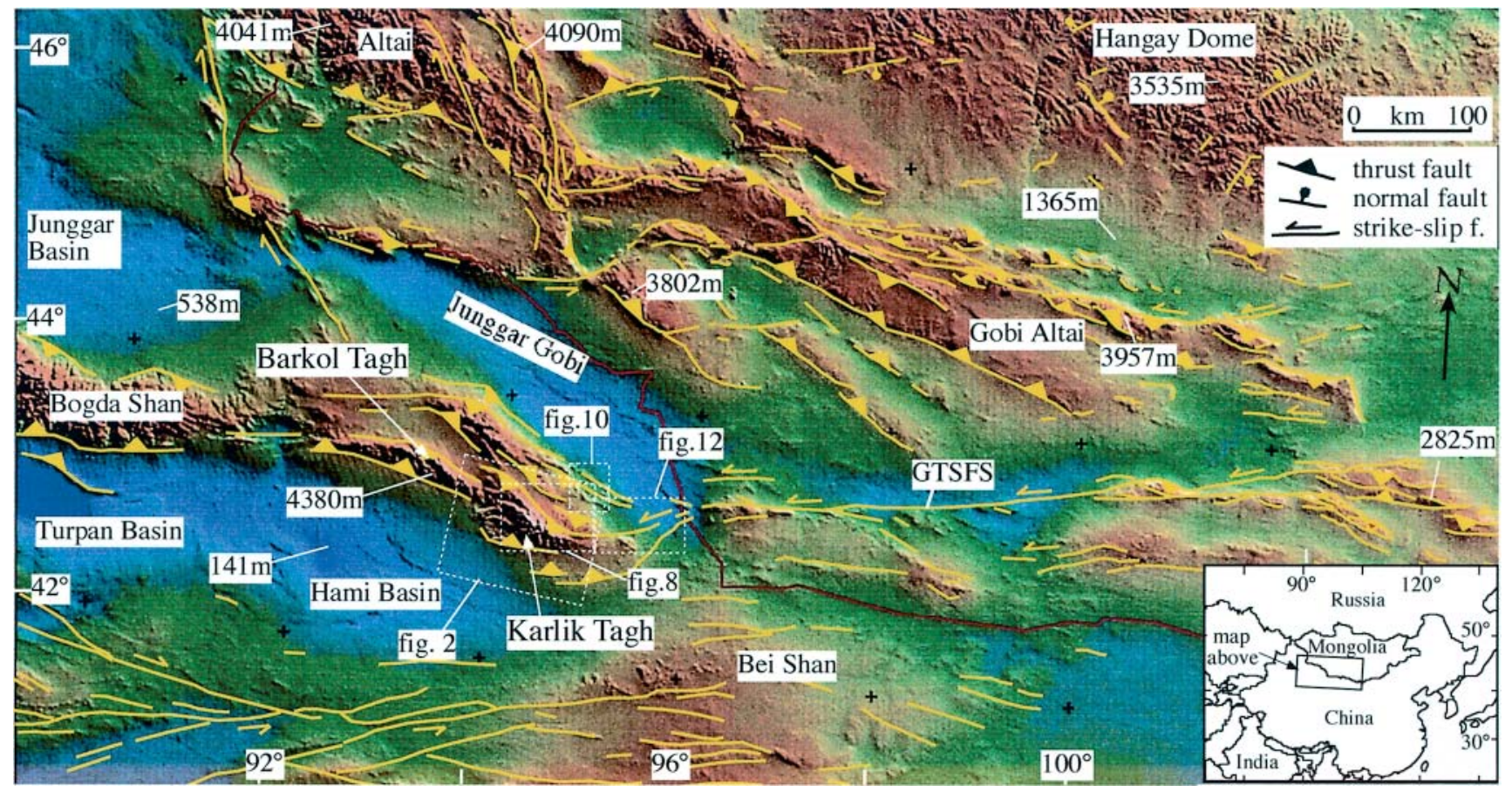

Fig. 1. Topographic map of easternmost Tien Shan and surrounding areas of western China and SW Mongolia showing major Cenozoic faults. Barkol and Karlik Tagh ranges form the extreme easternmost spur of the Tien Shan and are the focus of this study. Locations of some subsequent figures are shown. Faults in Karlik Tagh link with the Gobi-Tien Shan left-lateral strike slip fault system (GTSFS) in SW Mongolia. Faults compiled from image analysis and structural field studies by Tapponnier \& Molnar (1979), Cunningham et al. (1996a, 1996b, 1997) and Cunningham (1998, 2000).

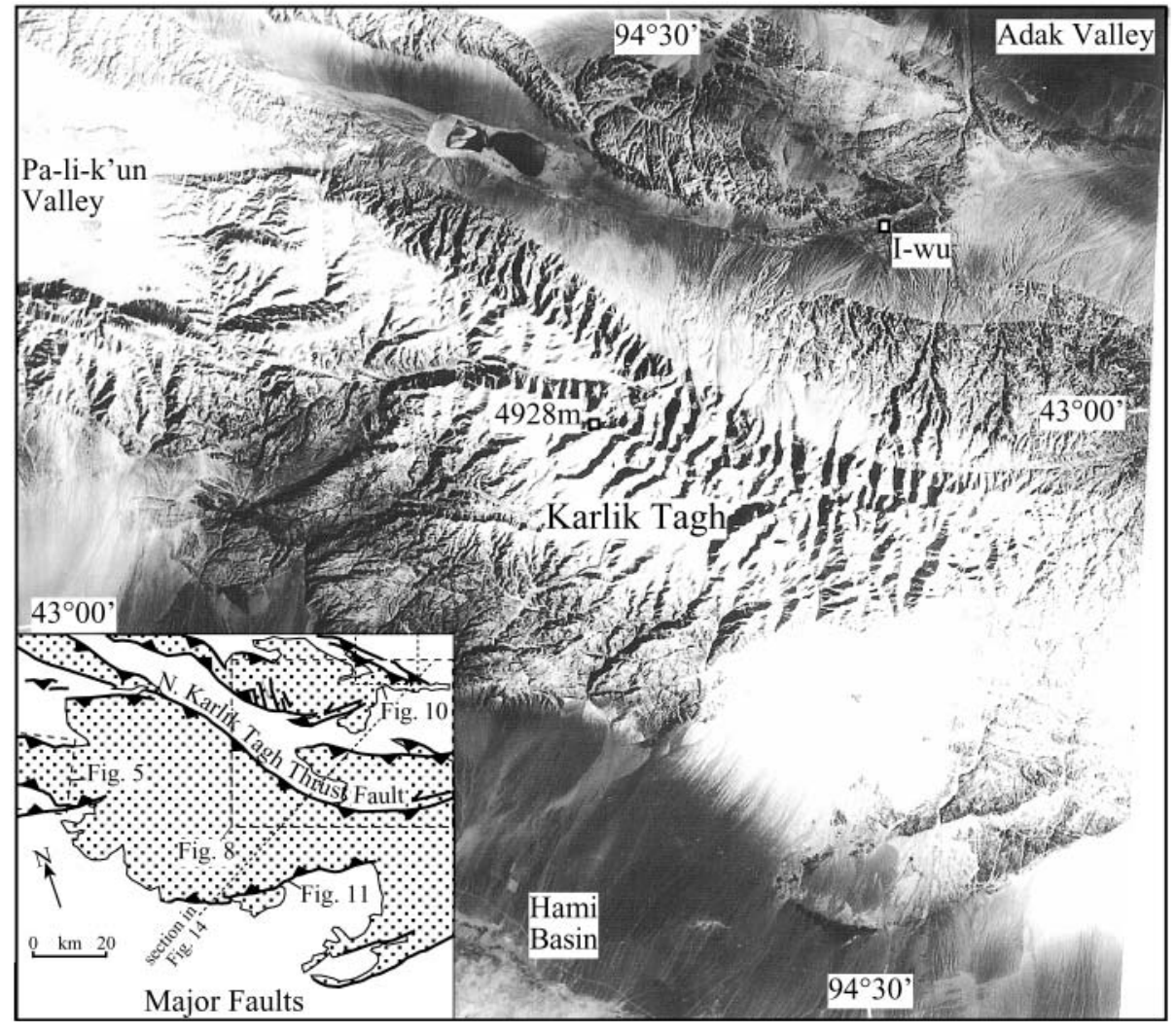

Fig. 2. MSS Landsat image of Karlik Tagh and surrounding areas. The sharply defined front along the northern margin of Karlik Tagh, which delimits the surface trace of the North Karlik Tagh Thrust Fault, should be noted. Inset map shows areas of basement exposure (patterned), major faults and locations of subsequent figures. 
building (Dumitru et al. 2001). It is likely that reactivation of the Tien Shan was facilitated by the range' s position directly north of the Precambrian Tarim Basin craton, which behaves as a rigid block. In contrast, the Tien Shan is largely underlain by mechanically weaker Palaeozoic arc rocks, accretionary complexes and ophiolitic assemblages that deform more easily in response to the north-northeasterly-derived compressive stress from the Indo-Eurasian collision (Westaway 1995; Neil \& Houseman 1997; Zhou et al. 2001).

The Tien Shan is structurally linked with the Pamir and other thrust-bounded ranges in the far west and NW, whereas in the east the range eventually dies out in the relatively flat western Gobi Desert (Fig. 1), suggesting an easterly decrease in the amount of shortening. For much of its length, the 3D fault architecture within the orogenic core is documented only along a few highways that cross the range (Burtman 1975; Allen et al. 1993a, b; Zhou et al. 2001). The external zones are much better studied, and active, outward-propagating thrust faults are documented on both north and south sides of the range deforming foreland basin sediments along the length of the chain (e.g. Tapponnier \& Molnar 1979; Peng \& Zhang 1989; Feng et al. 1991; Avouac et al. 1993; Cobbold et al. 1996; Yin et al. 1998; Allen et al. 1999; Burchfiel et al. 1999; Hubert-Ferrari et al. 1999). Current shortening rates calculated for the Tien Shan are of the order of $13 \pm 7 \mathrm{~mm} \mathrm{a}^{-1}$ (Molnar \& Deng 1984), with rates in the eastern Tien Shan of the order of $6 \pm 3 \mathrm{~mm} \mathrm{a}^{-1}$ and rates in the western Tien Shan as high as $2 \mathrm{~cm} \mathrm{a}^{-1}$ (Avouac \& Tapponnier 1993; Abdrakhmatov et al. 1996; Hager et al. 1996; Molnar \& Ghose 2000), which is estimated to be between $5 \%$ (eastern) and $40 \%$ (western) of the total annual shortening taken up by Central Asia as a result of collision with India (Avouac et al. 1993; Wang et al. 2001).

\section{Methods}

Analysis of Landsat, Kosmos and Space Shuttle images was carried out before fieldwork to help identify areas of Cenozoic faulting and interesting tectonic landforms in the Barkol Tagh and Karlik Tagh region (Fig. 1). Detailed structural transects were undertaken in Barkol Tagh and Karlik Tagh and across smaller parallel ranges in the region to document the cross-strike structure, fault kinematics, polyphase evolution and extent of crustal shortening. Small-scale mapping was carried out locally in areas of special interest. Work was also carried out ENE of Karlik Tagh to better understand the fault systems that link the easternmost Tien Shan with mountains in SW Mongolia. Samples of fault zone mylonites were collected for thin-section analysis to determine shear sense and for Ar-Ar dating.

\section{Physiography of the Karlik Tagh region}

Although Karlik Tagh is the easternmost range of the Tien Shan, it is a major topographic culmination, rising to a maximum elevation of $4928 \mathrm{~m}$ above sea level (a.s.1.) immediately north of the Hami Basin, which descends as low as $50 \mathrm{~m}$ a.s.l. The range appears as a singular high asymmetric ridge $c .50 \mathrm{~km}$ wide and $200 \mathrm{~km}$ long, and contains large valley glaciers and an impressive ice cap that covers c. $200 \mathrm{~km}^{2}$. The range has strongly asymmetric drainage patterns, with long canyons on its south side, short drainages on its north side and the main drainage divide considerably closer to the northern front than the southern front (Fig. 2). When viewed from the west or south at long range, Karlik Tagh's asymmetric topography suggests, at first order, a short northern scarp slope and a long south-sloping dip slope. The south slope is generally planar except where incised by glacial or fluvial valleys and is a remnant peneplain of late Cretaceous-early Tertiary age (Fig. 3), which is well developed in western Mongolia and adjacent regions of China (Devyatkin 1974). The peneplain is also locally present in Barkol Tagh. The presence of this peneplain suggests that before Late Cenozoic reactivation of the easternmost Tien Shan, the range was bevelled flat or had very subdued topography.

\section{Regional geology of Barkol Tagh and Karlik Tagh}

The oldest known rocks in the region are Ordovician lowgreenschist grade phyllites and slates that crop out in several belts in northern Karlik Tagh (Fig. 4). Younger Palaeozoic sedimentary and volcanic lithologies occur widely (Regional Survey Team, Xinjiang Geological Bureau 1966a, 1966b, 1966c, 1966d). Numerous undated granitic and dioritic plutons intrude the Palaeozoic rocks and form large areas of Karlik Tagh and Barkol Tagh. The intrusive and volcanic rocks are part of a Carboniferous arc complex that can be traced farther west into Bogda Shan (Windley et al. 1990) and eastwards into southern Mongolia (Lamb \& Badarch 2001). Limited Mesozoic clastic

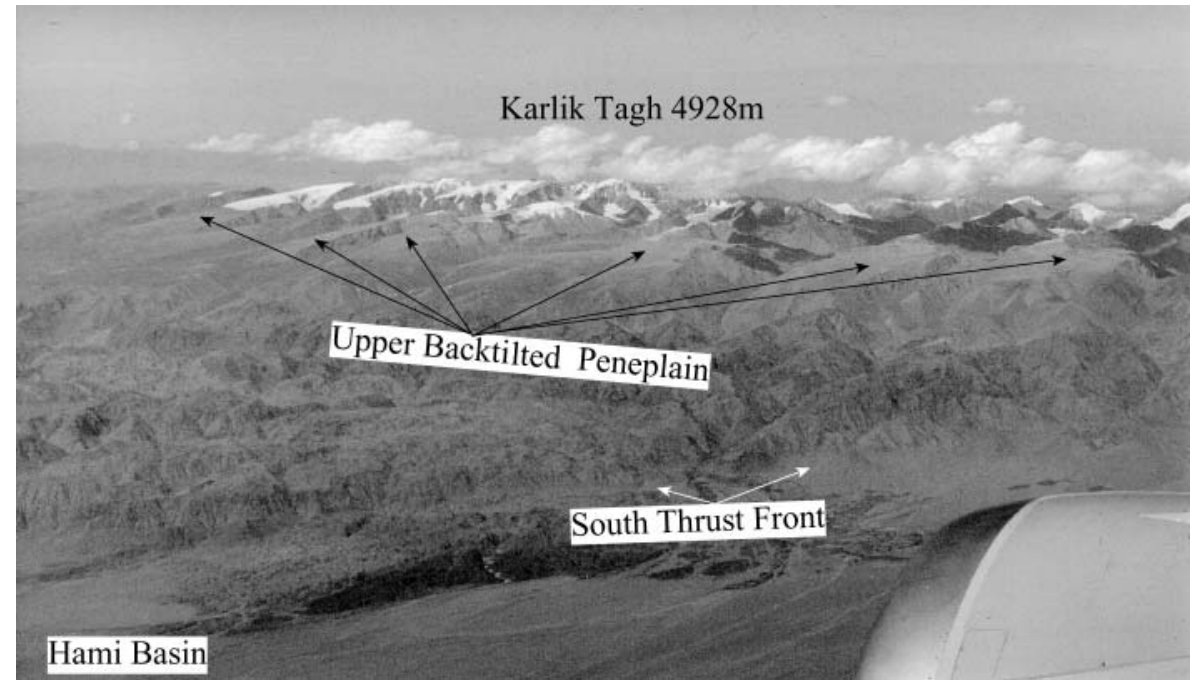

Fig. 3. Oblique aerial photograph looking north of Karlik Tagh range, which is the easternmost topographic culmination of the Tien Shan. Summit ridge with icecap and valley glaciers and preserved south-tilted remnant peneplain should be noted. Uplift along the south thrust front has forced canyon incision in lower parts of range. 


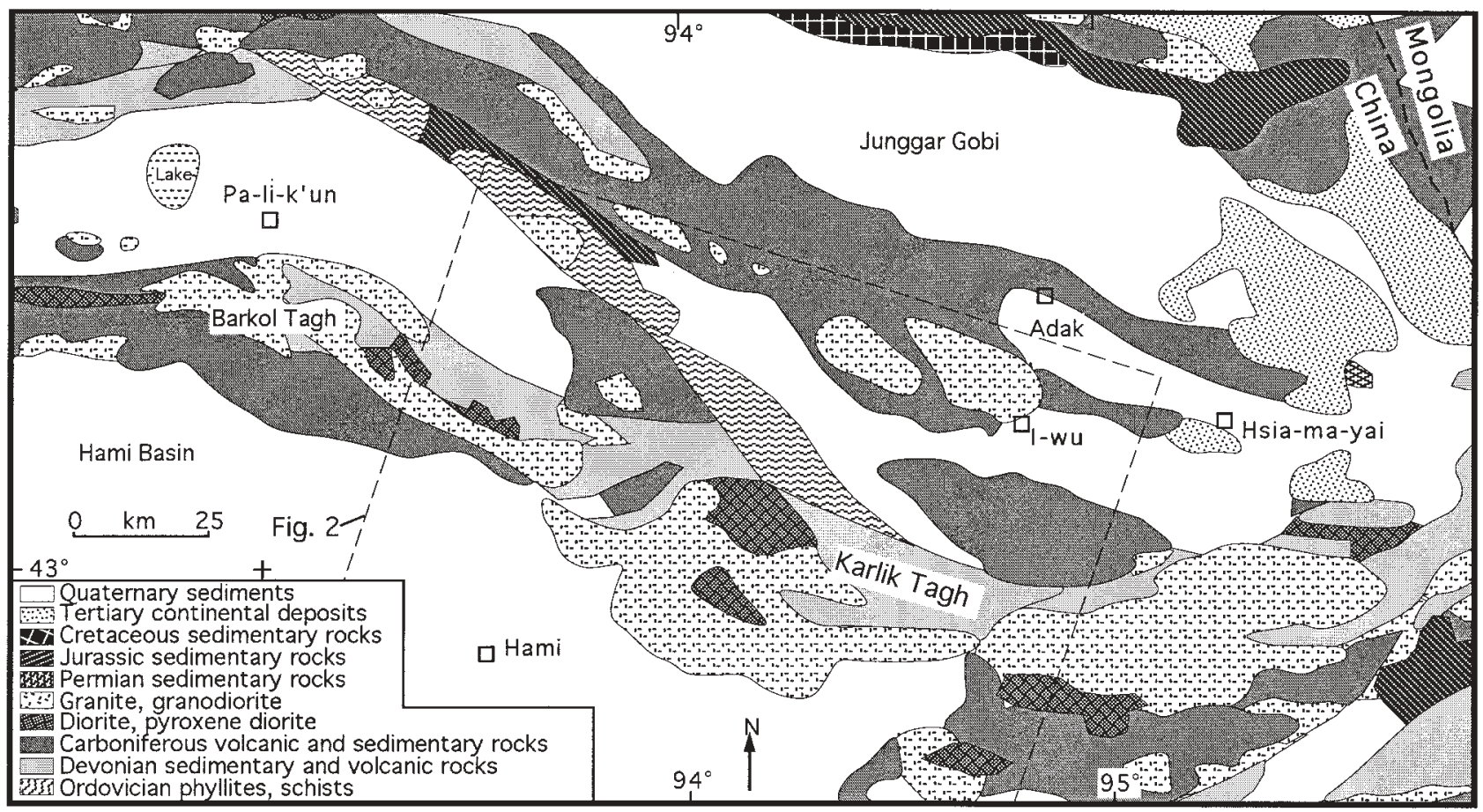

Fig. 4. Geological map of easternmost Tien Shan in eastern Xinjiang Province, China, showing major rock types only. Geology taken from 1:2 000 000 map published by the Bureau of Geology and Mineral Resources of Xinjiang Uygur Autonomous Region (Chen 1983).

sequences occur in several belts and in the subsurface stratigraphy of the Hami and Junggar basins (Hendrix 2000; Fig. 4). Late Tertiary and Quaternary glacial, alluvial and lacustrine sediments are widespread adjacent to the mountains and in intermontane basins. Known Cenozoic faults in the easternmost Tien Shan region and adjacent regions of SW Mongolia are shown in Figure 1.

\section{Geology of Barkol Tagh}

A structural transect was made across eastern Barkol Tagh following the main road that leads from $\mathrm{K}$ 'ou-men-tzu village to Hami (Fig. 5). At the northern mountain front $\left(43^{\circ} 20.786^{\prime} \mathrm{N}\right.$, $\left.93^{\circ} 39.339^{\prime} \mathrm{E}\right)$, quartz-muscovite schists crop out that are strongly mylonitized with $268^{\circ}$-striking, $60^{\circ}$ south-dipping foliation planes. Well-developed $\mathrm{S}-\mathrm{C}$ fabrics indicate a north-directed thrust sense. A prominent stretched quartz and mica aggregate lineation plunges at $57^{\circ}$ towards $202^{\circ}$, suggesting a component of left-lateral displacement associated with thrusting at this location. Minor brittle thrusts cut through the succession.

Structurally above the frontal quartz-muscovite tectonites is a Devonian metavolcanic sequence (Regional Survey Team, Xinjiang Geological Bureau 1966d) containing grey chloritic schists and phyllites that contain massive layers of volcaniclastic greenstone. The metamorphic fabric is layer-parallel where observed and fairly homoclinal throughout the succession, striking approximately east-west and dipping at $50-70^{\circ} \mathrm{S}$. Ductile strain intensifies down section towards the northern mountain front as indicated by an increase in foliation-plane density, lineation development and $\mathrm{S}-\mathrm{C}$ fabric development.

Further up section the geology is dominated by a succession of unmetamorphosed but strongly fractured and veined blocky andesites, basalts and tuffaceous rocks. They are cut by a major brittle thrust zone that is expressed as a sheared breccia with numerous north-directed thrust planes (Fig. 5). At the top of the pass, mylonitized chloritic metabasite crops out over a structural thickness of at least $100 \mathrm{~m}$. This important shear zone contains well-developed $\mathrm{L}-\mathrm{S}$ tectonites striking $260^{\circ}$ and dipping $36^{\circ} \mathrm{SE}$ with quartz and chlorite lineations plunging at $35-150^{\circ}$. Subtle asymmetric fabrics and minor folds suggest north-directed thrusting. South of this shear zone, ductile strain decreases and a sequence containing folded low-grade metamorphosed and cleaved mudstones crops out. The most notable structural feature in these rocks is a strongly developed late-stage array of kink bands that strike $270^{\circ}$ and dip $40^{\circ} \mathrm{N}$, deforming the older cleavage and bedding. The kink bands show top-to-the-south sense and taken together represent south-directed thrust motion perhaps conjugate to the major thrust shear zone directly to the north (Fig. 5).

South of the deformed mudstones, massive unmetamorphosed mafic volcanic flows, breccias and agglomerates crop out that are intruded to the south by a major undeformed granite and diorite intrusive body. No major structures were identified within these units and thus they appear to have been uplifted as a large contiguous block.

The southern mountain front is marked by deformed Quaternary alluvial fan sediments that are tilted as much as $20^{\circ}$ to the north in stream sections. The northerly dips suggest back-tilting as a result of south-directed thrusting from below (Fig. 5) Likewise, the relatively steep front suggests it is faulted, with granite thrust over alluvial material at the mountain front. Further outboard, the fan sediments are cut by a prominent thrust fault that is visible on the satellite imagery (Fig. 5) and that back-tilts Neogene red beds $10^{\circ}$ to the north on its upper plate and overrides red beds that dip south as much as $50^{\circ}$. The fault zone is marked by springs where there are several small villages. 

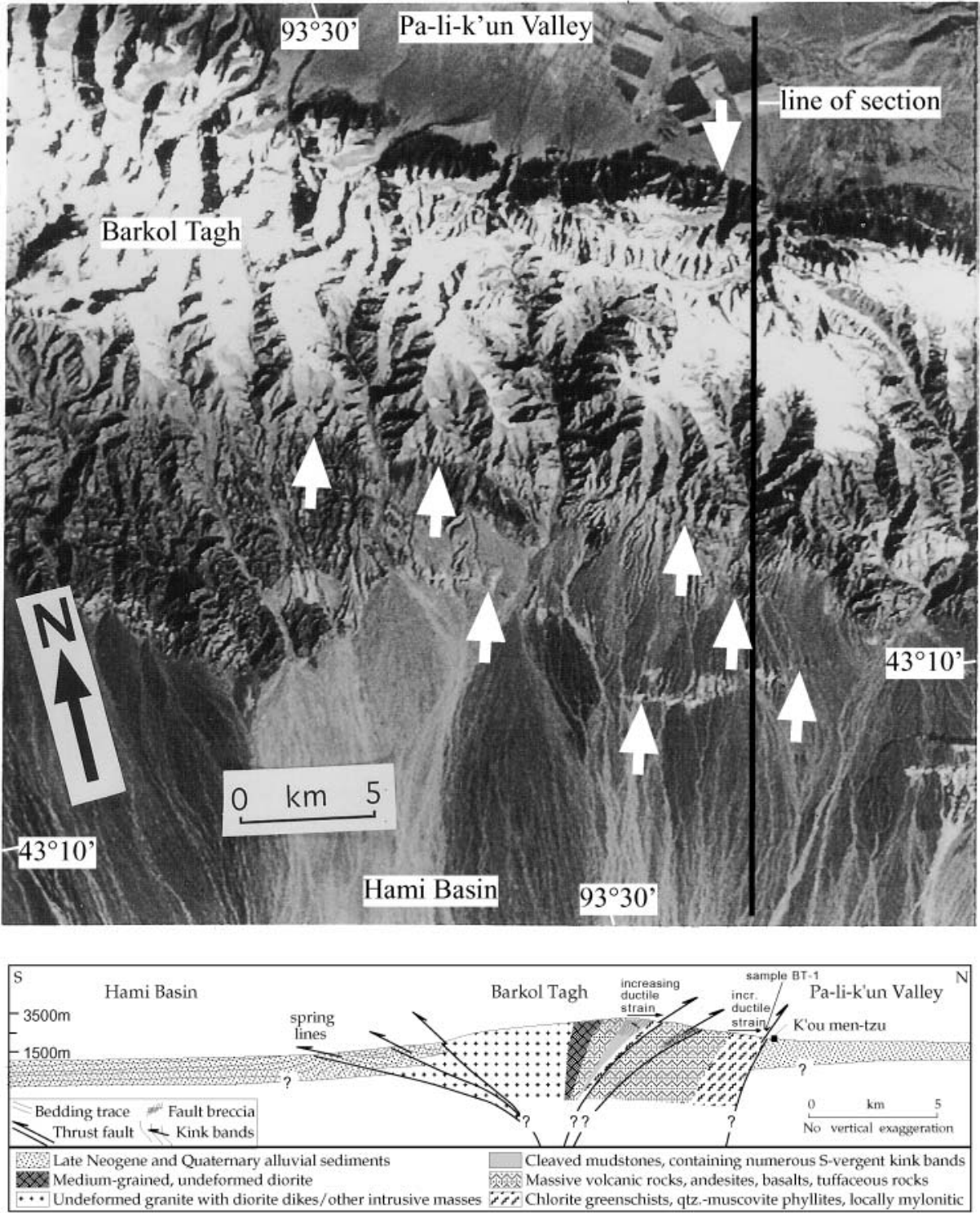

Fig. 5. Landsat close-up of eastern Barkol Tagh showing location of cross-section and thrust fault scarps that deform alluvial sediments on north and south sides of range (white arrows). Short drainages on north side and long canyons on south side of range should be noted; these suggest greater uplift of north side and bulk southward tilting of range. Cross-section indicates range is doubly vergent with outward directed thrusts on both sides. At north front, mylonitic rocks that have undergone brittle reactivation are exposed and were sampled for Ar/Ar dating (sample BT-1, Fig. 6).
At the line of the transect discussed here, Barkol Tagh is an uplifted block bounded by outward-directed thrust faults on both its north and south sides. The north side exposes Devonian metavolcanic and metapelitic units that have undergone ductile deformation whereas the south side exposes undeformed, undated (post-Devonian) granite and, further west along strike, Carboniferous sedimentary and volcanic lithologies (Regional Survey Team, Xinjiang Geological Bureau 1966d). This suggests that the rocks brought to the surface along the north side of the range are from a deeper level than those on the south side. The range is also topographically asymmetric, with steeper northern slopes with short steep drainages on the north side (Fig. 5) and longer, better developed drainages on its south side, suggesting more recent and greater uplift of the north side (Fig. 5). The general homoclinal nature of the metavolcanic, metasedimentary and volcanic sequence in the northern half of the range is also consistent with dominantly layer-parallel north-directed thrusting on south-dipping thrust planes as the major structures that have uplifted the range. Thus the range appears to have an asymmetric pop-up cross-sectional geometry with greater amounts of thrust displacement on its northern side.
White micas from mylonitized quartz-muscovite schists at the northern Barkol Tagh thrust were dated by the ${ }^{40} \mathrm{Ar} /{ }^{39} \mathrm{Ar}$ method. The age spectrum (Fig. 6) indicates a minor amount of ${ }^{40} \mathrm{Ar}$ loss in the lower-temperature steps. The higher-temperature part of the spectrum, which comprises c. $80 \%$ of the released ${ }^{39} \mathrm{Ar}$, exhibits a saddle shape suggestive of the incorporation of excess ${ }^{40} \mathrm{Ar}$. If so, the lowest age step in the U-shaped part of the spectrum is commonly interpreted to represent a maximum age estimate for the sample, in this case $247 \mathrm{Ma}$. The ${ }^{39} \mathrm{Ar}$ abundances and ${ }^{39} \mathrm{Ar} /{ }^{37} \mathrm{Ar}$ ratios are reasonable for potassium white mica, giving us confidence that $247 \mathrm{Ma}$ represents the closure age for this sample. Thus this thrust zone is interpreted to be a latest Permian-early Triassic ductile thrust zone that underwent brittle reactivation in the late Cenozoic.

\section{Northern margin of Karlik Tagh}

The northern front of Karlik Tagh is gently arcuate in plan view (Fig. 2) and in the west is marked by a sharply defined break in slope between bedrock and alluvial materials or as a clear scarp cutting Quaternary alluvium (Fig. 7). In the central and eastern 

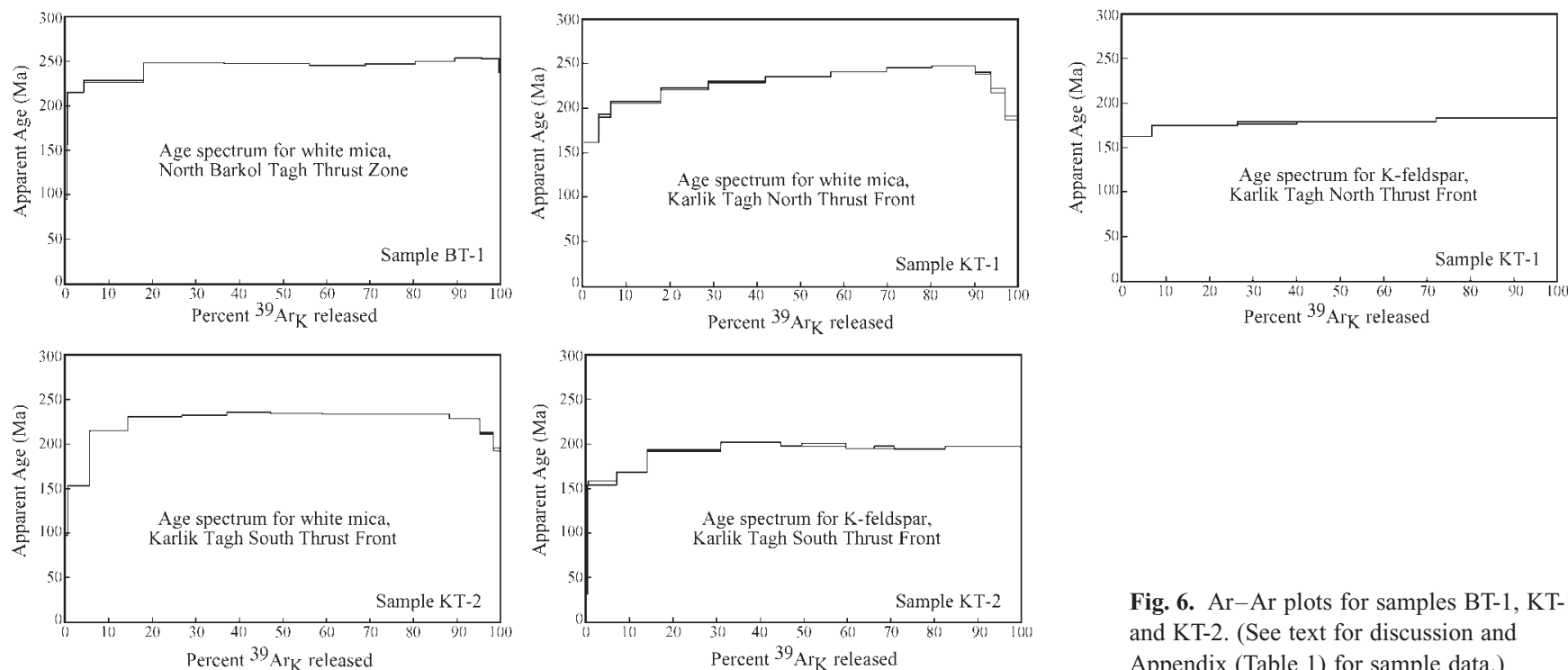

Fig. 6. Ar-Ar plots for samples BT-1, KT-1 and KT-2. (See text for discussion and Appendix (Table 1) for sample data.)

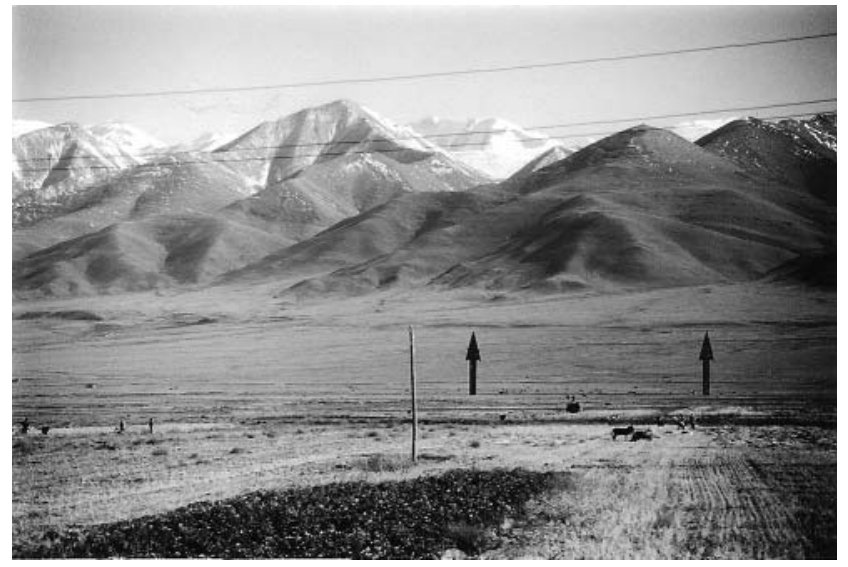

Fig. 7. Photograph of distant scarp (arrows) along northern front of Karlik Tagh in Yen-ch'ih Valley. Fault cuts alluvial deposits and is marked by a line of springs. (See Fig. 8 for location.)

parts of the range, the northern margin is also sharply defined, but separates bedrock from glacial and alluvial sediments or bedrock inliers. The low mountain front sinuosity suggests that the entire length of the northern front is marked by a major fault. Attempts were made to identify this frontal structure along three cross-strike transects (Fig. 8, sections A-B, C-D and E-F).

Section $\mathrm{A}-\mathrm{B}$ indicates that the northern front is composed of a homoclinal SW-dipping section of mixed Ordovician-Silurian clastic and volcaniclastic sedimentary rocks, and low-grade slates and phyllites. There is a clear increase in metamorphic grade and metamorphic texture in the lithologies towards the mountain front. Furthermore, there is an increase in ductile strain towards the mountain front. The most northerly exposed lithologies comprise quartzite mylonites that strike $286^{\circ}$, dip $54^{\circ} \mathrm{SW}$ and have quartz lineations that plunge moderately SE. The mylonites are banded and in thin section contain asymmetric fabrics suggesting northward thrusting. No obvious major fault or scarp is exposed at this location; however, several small, brittle, NEdirected thrust faults were observed to cut the succession farther up slope, suggesting that a larger thrust fault delimits the mountain front.

White mica and K-feldspar from the quartzite mylonites at the mountain front were dated by $\mathrm{Ar}-\mathrm{Ar}$ to determine the age of ductile thrusting (Fig. 6). The white mica age spectrum indicates apparent argon loss but the ${ }^{39} \mathrm{Ar}$ abundances are low for pure $\mathrm{K}$ white mica and the ${ }^{39} \mathrm{Ar} /{ }^{37} \mathrm{Ar}$ ratios suggest mixed $\mathrm{K} / \mathrm{Ca}$-ratio argon reservoirs contributing to the age pattern. The high- $T$ steps, especially, but also the lower- $T$ steps to some extent, are low in $\mathrm{K}$. The age spectrum suggests that the K-mica cooled at c. $250 \mathrm{Ma}$ and was partially reset at c. $160 \mathrm{Ma}$ (late Jurassic), or a lower-K phase is contributing to this part of the age spectrum. The K-feldspar, a small sample that was analysed in only five steps, shows a monotonic rise in apparent age from about 160 to $185 \mathrm{Ma}$. This may reflect cooling or the effect of partial resetting at about $160 \mathrm{Ma}$. Overall, the results indicate that ductile thrusting was latest Permian-early Triassic in age with possible partial resetting in the Late Jurassic. Late Cenozoic brittle reactivation of the thrust zone did not affect the Ar-Ar system.

Section C-D (Fig. 8) crosses the mountain front at a higher elevation than $\mathrm{A}-\mathrm{B}$ and continues to $3500 \mathrm{~m}$ elevation where valley glaciers are present. In this area, the mountain front is covered with unfaulted paraglacial fan deposits and highly eroded moraines. The northernmost outcrops consist of Ordovician chloritic slates, phyllitic metavolcanic rocks and slatey metapelitic rocks. Undeformed to weakly foliated diorite locally intrudes the succession. The low-grade metamorphic sequence has a strong foliation that generally obscures any earlier bedding and that defines a regional foliation fan that changes from $70^{\circ} \mathrm{SW}$-dipping attitudes at the northern front to vertical attitudes and then $55^{\circ} \mathrm{NE}$-dipping attitudes at the SW end of the transect. Within the SW-dipping and vertical sections of the foliation fan, numerous kink bands were observed that have SE-plunging crests and top to the NE motion sense, suggesting post-metamorphic left-lateral oblique-slip thrust motion along the North Karlik Tagh front has deformed the section.

Section E-F (Fig. 8) was examined at the eastern end of the range at a relatively low elevation (2000 $\mathrm{m}$ a.s.1.), where the fault forms a prominent narrow valley filled with fluvial sediments. There is a sharp metamorphic break across the valley between greenschists and greenschist mylonites on the south side and 


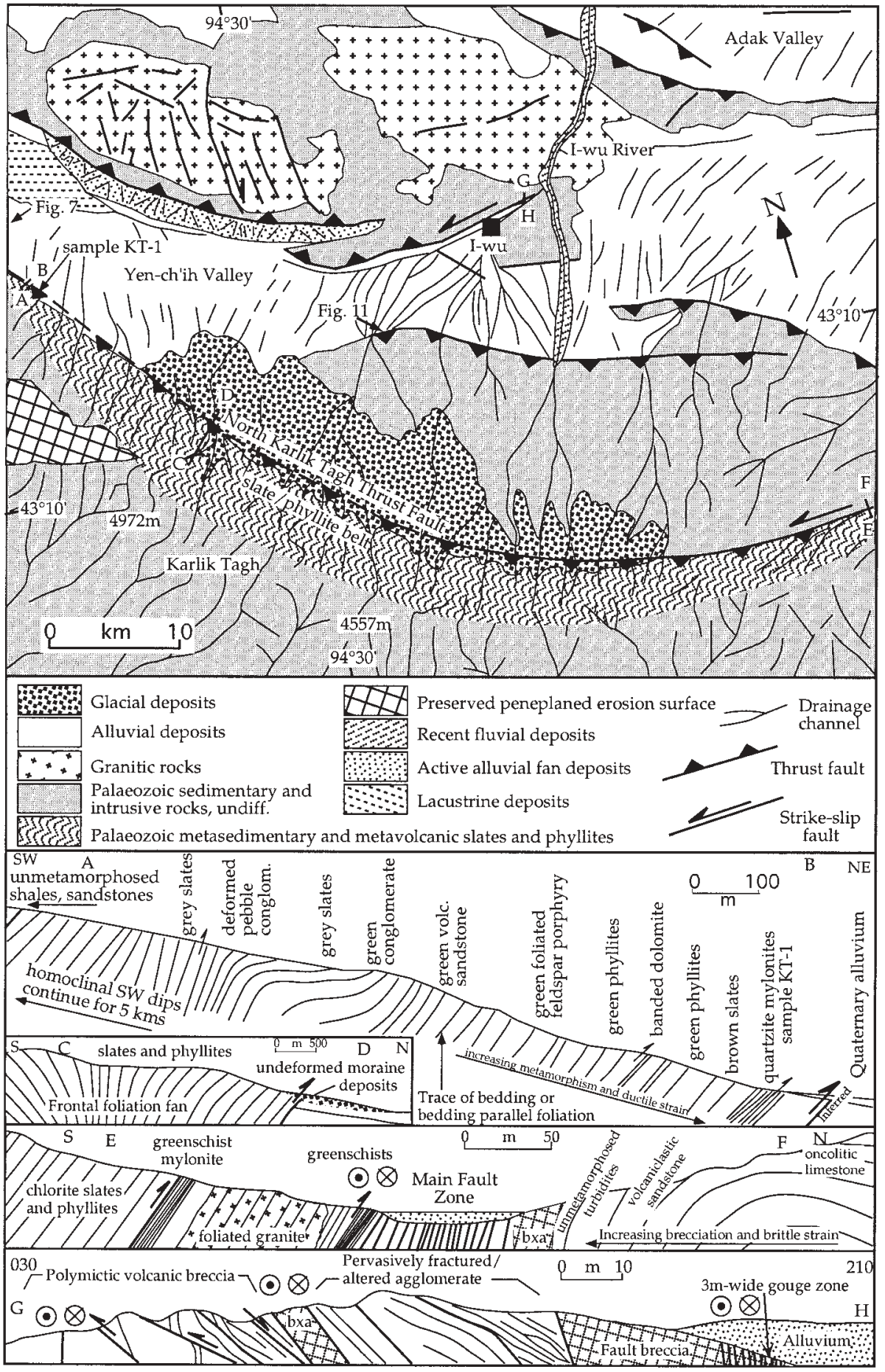

Fig. 8. Geological interpretation of northern Karlik Tagh and I-wu river valley with transect sections discussed in text. Landsat view of map area and location are shown in Figure 2. Location of Figure 9 is shown. unmetamorphosed, but brecciated, turbiditic sedimentary rocks on the north side. $\mathrm{S}-\mathrm{C}$ fabrics within the greenschists indicate south-side-up north-directed thrusting. Outcrops on the north side of the valley are increasingly brecciated towards the valley centre and contain discrete brittle vertical fault surfaces striking $290^{\circ}$.

Taken together, the three transects provide strong evidence for a major NE-directed thrust fault along the northern mountain front of Karlik Tagh, despite the fact that a major brittle fault plane was never observed directly. This evidence includes a clear topographic break and sharply defined front visible on the satellite imagery for over a $60 \mathrm{~km}$ length, an abrupt metamorphic break across the frontal structure with metamorphic rocks uplifted on the south side to form some of the highest elevations in the range, an increase in ductile and brittle strain towards the mountain front, $\mathrm{S}-\mathrm{C}$ fabrics and kink bands indicative of NEdirected thrusting, local small-scale brittle thrusts, and homoclinal SW-dipping bedding or foliation attitudes that are favourably oriented to allow layer-parallel northeastward thrusting. The $\mathrm{Ar}-\mathrm{Ar}$ dates from section A-B (Fig. 8) indicate that the frontal thrust zone is a Latest Permian-early Triassic ductile thrust zone 
that underwent brittle reactivation in the late Cenozoic. The regional geological map (Fig. 4) indicates that the highest-grade metamorphic rocks in the region, which have been exhumed from the greatest depths, occur directly adjacent to the frontal thrust fault. We call this fault the North Karlik Tagh Thrust.

\section{Major faults in the I-wu area}

Directly south of the town of I-wu, a prominent step-like ridge with a sharply defined linear northern front is visible on the Landsat imagery (Fig. 2, 'lower thrust front' in Fig. 9). At the northern outlet of the I-wu river, rocks along the mountain front consist of a succession of volcanic and sedimentary lithologies that form a frontal monocline with a south-dipping axial plane. These units are variably brecciated over a $300 \mathrm{~m}$ cross-strike width, indicating that a major fault buried beneath alluvium defines the range front.

Near the western end of the ridge, the frontal fault is exposed in several prospectors' pits (Fig. 9 inset) as a discoloured gouge zone penetratively cut by shear surfaces. The fault places massive fractured greenstones over relatively undeformed feldspar andesite porphyry. The sheared fabric strikes $288^{\circ}$ and dips $62^{\circ} \mathrm{SW}$. Slickenlines are poorly preserved in the crumbly gouge material, but locally suggest down-dip to shallow SW plunges. The fault is interpreted as a north-directed reverse fault with a possible minor left-lateral strike-slip component.

The town of I-wu sits astride a major fault that is well exposed west and east of the town and forms an obvious east-trending lineament on the satellite imagery (Figs 2 and 8). The fault separates brecciated porphyritic Carboniferous andesite in the north from $80^{\circ} \mathrm{S}$-dipping, cemented brown conglomerates of Tertiary-Quaternary age. The fault zone is well exposed as a gouge zone of $1 \mathrm{~m}$ width within a shattered breccia zone of $20 \mathrm{~m}$ width that strikes $090^{\circ}$ and dips $88^{\circ} \mathrm{S}$. The fault is visually obvious because of the sharp colour contrast between the lithologies across the zone and the broken nature of the fault rocks. On horizontal exposures, left-lateral offsets of steep veins and brittle slip planes are present. Sheared surfaces within the gouge zone are asymmetric and locally have $\mathrm{S}-\mathrm{C}$ geometries that indicate left-lateral shear sense on near-vertical east-west planes.
At the eastern end of town, the fault cuts through outcrops near the I-wu river (transect G-H, Fig. 8) and is also represented by a major gouge zone and thick breccia in the adjacent wall rock. Left-lateral strike-slip motion is indicated by offset brittle fractures and veins. This fault strikes northwesterly at its western end and terminates at a small isolated ridge at the eastern end of the Yen-ch'ih Valley, where left-lateral motion is transferred to south-directed thrust motion (Figs 2 and 8).

\section{Ranges north of I-wu}

North of I-wu, the I-wu river follows a regional northward slope down to the Junggar Gobi Basin (Figs 1, 2 and 8). Interrupting the regional northward slope are two uplifted ranges on either side of the Adak valley that show evidence for Cenozoic tectonic activity (Fig. 10).

The unnamed ridge that forms the southern boundary to the Adak valley is composed of SW-dipping Carboniferous sandstones that dip between 30 and $50^{\circ} \mathrm{SW}$ for several kilometres across strike. The mountain front is mantled with Quaternary alluvial fans obscuring any frontal fault. Several kilometres north of the front a north-directed thrust fault breaches the surface in the west and thrusts Neogene sediments to the surface over Quaternary sediments, whereas in the east, the same fault is a blind thrust with a fault propagation fold above that deforms surface materials. Similar thrust ridges bring tilted Neogene red beds to the surface near the northern margin of the Adak valley (Fig. 10) and indicate that the valley is being overthrust on both its north and south sides.

Adak ridge (Fig. 10) is composed of green chloritic slates, phyllites and massive greenstones that contrast strongly with other lithologies in the surrounding area that are unmetamorphosed. The southern front is marked by a major fault zone that thrusts brecciated greenstones over back-tilted (up to $65^{\circ} \mathrm{SW}$ ) Neogene red beds. Numerous north-dipping brittle thrust zones cut the brecciated rock in exposures along the I-wu river where the river enters the range. Within the range, the metamorphic foliation defines a flower-like foliation fan and recumbent fold. The northern limb of this fold is relatively homoclinal with SWdipping fabrics occurring for several kilometres to the northern range front. The northern range front is fairly sharply defined on

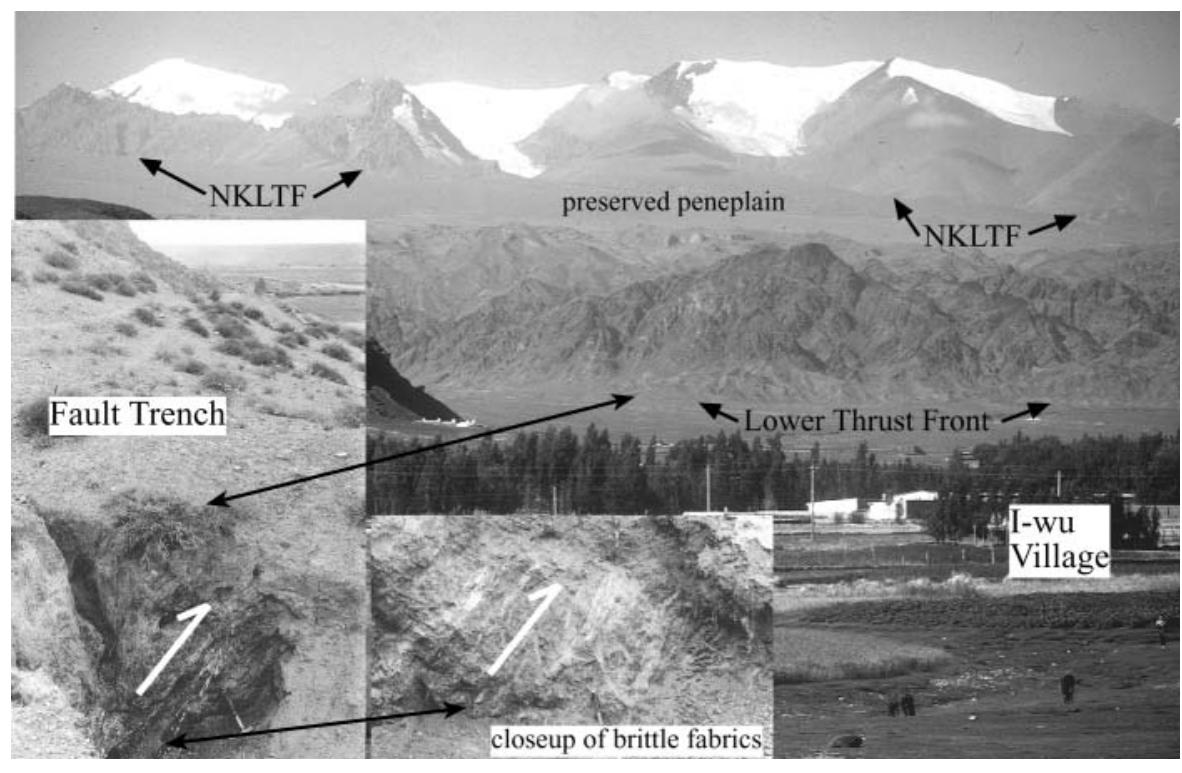

Fig. 9. View looking south from town of Iwu to northern front of Karlik Tagh. Steplike ridge in middle distance with frontal thrust, hanging-wall canyons and rearward preserved peneplain should be noted. North Karlik Tagh Thrust Fault (NKLTF) forms prominent break in slope above peneplain. I-wu river valley is in foreground. Distant summits exceed $4500 \mathrm{~m}$ and glaciers provide source for I-wu river. Inset photographs show views looking west of excavation of lower thrust fault containing sheared breccia and gouge. Thrust strikes $288^{\circ}$, dips $62^{\circ} \mathrm{SW}$ and places massive fractured greenstones over relatively undeformed feldspar andesite porphyry. (See Fig. 2 for Landsat view of thrust front.) 


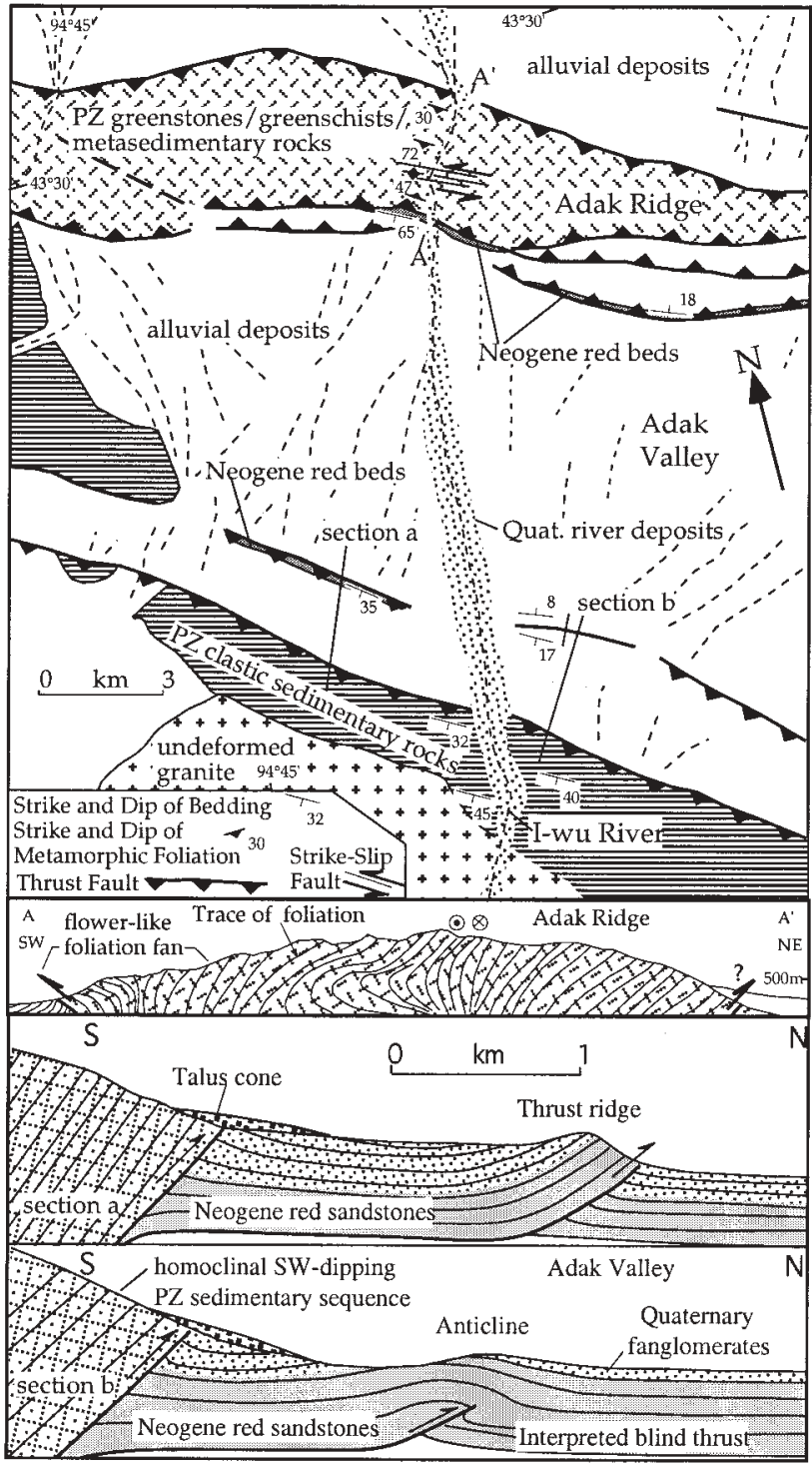

Fig. 10. Geological interpretation of Landsat scene of the Adak valley and ridges bordering it. (See Figs 1 and 2 for location.) Thrust ridges in southern and northern Adak valleys that deform Quaternary alluvial deposits should be noted. Also shown are structural sections along I-wu river canyon, which cuts through Adak ridge and across thrust ridges in southern part of basin.

satellite imagery, but is mantled with alluvium and no definitive evidence for an active range-bounding fault was found.

\section{Southern margin of Karlik Tagh}

The southern mountain front of Karlik Tagh is bounded by a major south-directed thrust fault that is well exposed at $42^{\circ} 52.144^{\prime} \mathrm{N}, 94^{\circ} 19.030^{\prime} \mathrm{E}$ in an area that is relatively free of alluvial deposits (Figs 2 and 11). The brittle fault zone is at least $50 \mathrm{~m}$ wide and places ultramylonitic granite (Fig. 11) above unfoliated granite. The zone strikes $080^{\circ}$, dips $39^{\circ} \mathrm{NW}$ and contains down-dip quartz lineations within the mylonite. The mylonitic fabric in the granite is developed only along the mountain front and increases in intensity towards the frontal fault zone. Further upslope, the granite is undeformed. A zone of soft brittle fault breccia and clay gouge of $>6 \mathrm{~m}$ thickness is exposed directly beneath the ultramylonite where small debris flows have stripped off the talus cover (Fig. 11). The combination of southdirected ductile shearing in the upper-plate granite and brittle brecciation in the fault zone directly below suggests that the fault is a reactivated and exhumed ductile thrust zone.

White mica and $\mathrm{K}$-feldspar from the mylonitized granite were dated by $\mathrm{Ar}-\mathrm{Ar}$ to determine the age of ductile thrusting. The white mica shows low $\mathrm{K} / \mathrm{Ca}$, probably reflecting a mixture of $\mathrm{K}$ white mica and chlorite. The age spectrum shows an intermediate temperature age hump that commonly results if ${ }^{39} \mathrm{Ar}$ is recoiled from chlorite during irradiation (Hess \& Lippolt 1986; Lo \& Onstott 1989); the spectrum also suggests some argon loss in the lower and higher temperature step. However, an apparent age of c. $230 \mathrm{Ma}$ (early-mid-Triassic) is indicated (Fig. 6). The Kfeldspar has relatively abundant ${ }^{39} \mathrm{Ar}$ but low ${ }^{39} \mathrm{Ar} /{ }^{37} \mathrm{Ar}$ ratios resulting from admixed quartz in the separate. Even though there is minor excess argon in the majority of the age spectrum, $200 \mathrm{Ma}$ is a good estimate for high-temperature cooling. The lower temperature of the spectrum may reflect lower-temperature cooling or partial resetting at $c$. 155-160 Ma (late Jurassic).

Another important south-directed brittle thrust was documented c. $3 \mathrm{~km}$ north of the southern mountain front along a stream valley at $42^{\circ} 55.161^{\prime} \mathrm{N}, 94^{\circ} 42.351^{\prime} \mathrm{E}$. At this location, a succession of chloritized volcaniclastic sedimentary rocks are overthrust by a massive undeformed quartz diorite. The fault zone strikes $076^{\circ}$ and is marked by steeply north-dipping $\left(>70^{\circ}\right)$ mylonitized greenschists that contain well-developed S-C fabrics and asymmetric porphyroclasts indicating top-to-the-south thrusting. The contact between the greenschists and the quartz diorite is marked by a steepening of fabrics into near-vertical attitudes and brecciation of the quartz diorite. In addition, a moderately dipping brittle thrust plane of $5 \mathrm{~cm}$ thickness slices up through the section and causes drag of adjacent wall rock also indicating south-directed thrust sense. Thus this fault zone also appears to have a ductile history with a brittle overprint.

\section{Eastern end of Karlik Tagh}

The North Karlik Tagh Thrust can be traced on satellite imagery towards the east, where it gradually and smoothly changes its trend from east-west to NE-SW (Figs 2 and 12). Correlating with this change in trend is a diminution of uplifted topography adjacent to the fault, which represents the eastern, final ridges of the Tien Shan. The fault can be linked farther east in Mongolia with a major left-lateral strike-slip fault system previously referred to as the central Gobi Fault (Tapponnier \& Molnar 1979) or Gobi Tien Shan Fault System (Khil'ko et al. 1985; Cunningham et al. 1996a). This can be traced on satellite imagery over an east-west length of $>400 \mathrm{~km}$ through the Gobi Altai region of southern Mongolia (Fig. 1). The correlation between diminishing topography and change in trend of the North Karlik Tagh Thrust fault trace in eastern Karlik Tagh suggests that the thrusting component along the North Karlik Tagh Thrust diminishes as it becomes northeasterly striking and the left-lateral strike-slip component increases (Fig. 12).

Northeast of Karlik Tagh and east of Hsia-ma-yai (Fig. 12), the fault is visible on the Landsat imagery as a prominent linear scarp that cuts surface materials over a length of $c .8 \mathrm{~km}$. Close examination of the scarp on the imagery indicates that two prominent drainages are offset in a left-lateral sense (Fig. 12, inset).

On the ground, the fault is marked by a semi-continuous ridge 


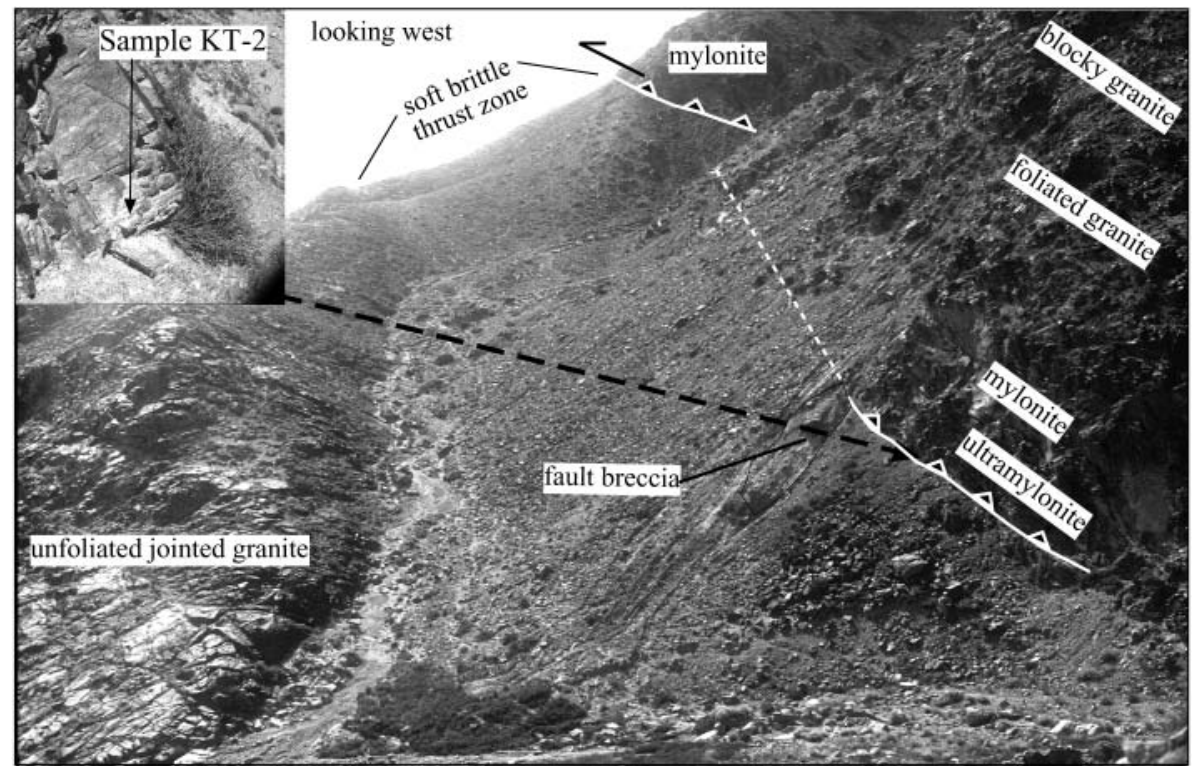

Fig. 11. View looking west of thrust zone along southern boundary of Karlik Tagh at $42^{\circ} 52.144^{\prime} \mathrm{N}, 94^{\circ} 19.030^{\prime} \mathrm{E}$. Thrust strikes $080^{\circ}$, dips $39^{\circ} \mathrm{NW}$ and contains down-dip stretching lineations in upper-plate mylonites. Inset photograph shows ultramylonitic granite in upper plate of thrust zone where sample KT-2 was taken. Photograph shows coherent mylonitized granite that has undergone ductile deformation above and broken fault breccia that has undergone brittle reactivation and gouge below (hammer). Ar/Ar ages indicate ductile fabrics formed during early Triassic thrusting and were reactivated by brittle Cenozoic thrusting. (See Fig. 2 for location of photograph.)

of $2-10 \mathrm{~m}$ height trending $230^{\circ}$ across a nearly flat featureless plain of barren windswept desert $\left(43^{\circ} 11.336^{\prime} \mathrm{N}, 95^{\circ} 44.092^{\prime} \mathrm{E}\right)$. The ridge is marked by a line of saxaul trees that are found nowhere else for many kilometres, indicating a shallow water table at depth and ephemeral spring line (Fig. 12 inset). The ridge clearly disrupts and beheads dry stream channels. The SE side of the ridge generally has higher, slightly uplifted elevations and locally contains fine sheet-like mud deposits that formed by channel runoff that ponded behind the ridge. Within these fine mud deposits are numerous crater and mound-like features up to $30 \mathrm{~cm}$ high that appear to be relict palaeoseismic liquefaction structures.

The southwestern end of the surface fault trace in this area is marked by a small isolated hill (location A, Fig. 12 inset) that rises $30-40 \mathrm{~m}$ above the surrounding plain. This hill has a steep SE slope and gentle upwarped NW slope that is a continuation of the desert pavement surface to the NW. Tilted Quaternary fanglomerates that dip $11^{\circ}$ to the NW can be seen in a few cuts, indicating Quaternary deformation.

\section{Discussion of 3D crustal structure and regional implications}

Our field observations indicate widespread Cenozoic deformation on both the north and south sides of Karlik Tagh, ENE of Karlik Tagh, in the I-wu area, Adak valley and on the north and south sides of Barkol Tagh. Quaternary sediments are deformed in many locations, but absolute ages of deformation are unknown. The glacial deposits on the north slope of Karlik Tagh do not appear to be cut, suggesting that the North Karlik Tagh Thrust Fault in that area was inactive during the Late Quaternary.

Based on our field observations and satellite image interpretations, a block model is proposed for the Karlik and Barkol Tagh regions of the easternmost Tien Shan (Fig. 13). This model shows the major Cenozoic faults in relation to topography and attempts to incorporate cross-sectional views of interpreted fault linkage at depth. The subsurface geology is speculative and generally assumes that the faults steepen with depth and that shortening is regionally partitioned into separate thrust ridges that have asymmetric flower structure cross-sectional geometries. This assumption is made because most ranges are doubly vergent and downward extrapolation of surface thrusts requires them to root into some structure. The existence of a shallow-dipping regional décollement as a basal structure is considered unlikely because of the opposite structural vergence on either side of each range and because the North Karlik Tagh Thrust links along strike with the steeply dipping Gobi-Tien Shan left-lateral strike-slip fault system. There is no evidence that any of the ranges are inverted pre-Cenozoic graben because none of the ranges have Pre-Cenozoic continent-derived clastic fill preserved in their interiors and reactivated faults contain older thrust fabrics, not extensional fabrics.

The overall deformation regime is transpressional, with thrusting occurring on NW-striking faults and left-lateral strike-slip and oblique-slip motion on east- and NE-striking faults (Fig. 13). This pattern is consistent with the predicted north-northeasterly maximum horizontal stress for the region (Zoback 1992). Except in the easternmost areas, strike-slip displacements appear to be secondary components of the overall Cenozoic deformation. Drainage length asymmetries in Barkol and Karlik Tagh (with short steep drainages on the north sides and long gentle gradient drainages on the south sides; Figs 2 and 5) suggest greater and faster uplift of the northern front of both ranges and bulk southward tilting. Thus the North Karlik Tagh Thrust Fault and the thrust fault at the north front of Barkol Tagh appear to be the dominant thrust faults in the region.

Preserved tilted Cretaceous-Palaeocene peneplain surfaces on the south flank of Karlik Tagh (Fig. 3) and above the lower thrust north of I-wu (Fig. 9) provide useful constraints on the amount of Cenozoic shortening across Karlik Tagh (Fig. 14, and section line in Fig. 2 inset). Assuming that these two surfaces are correlative and that the same surface is uplifted on Adak ridge, then a minimum estimate of thrust-related Cenozoic shortening between the Hami Basin and Adak valley is $5-6 \mathrm{~km}$. This estimate is based on straight projection of peneplain surfaces and fault planes into space where they have been eroded (Fig. 14). Surface fault dip values are extrapolated to depth and thus horizontal shortening may be underestimated if faults shallow at 

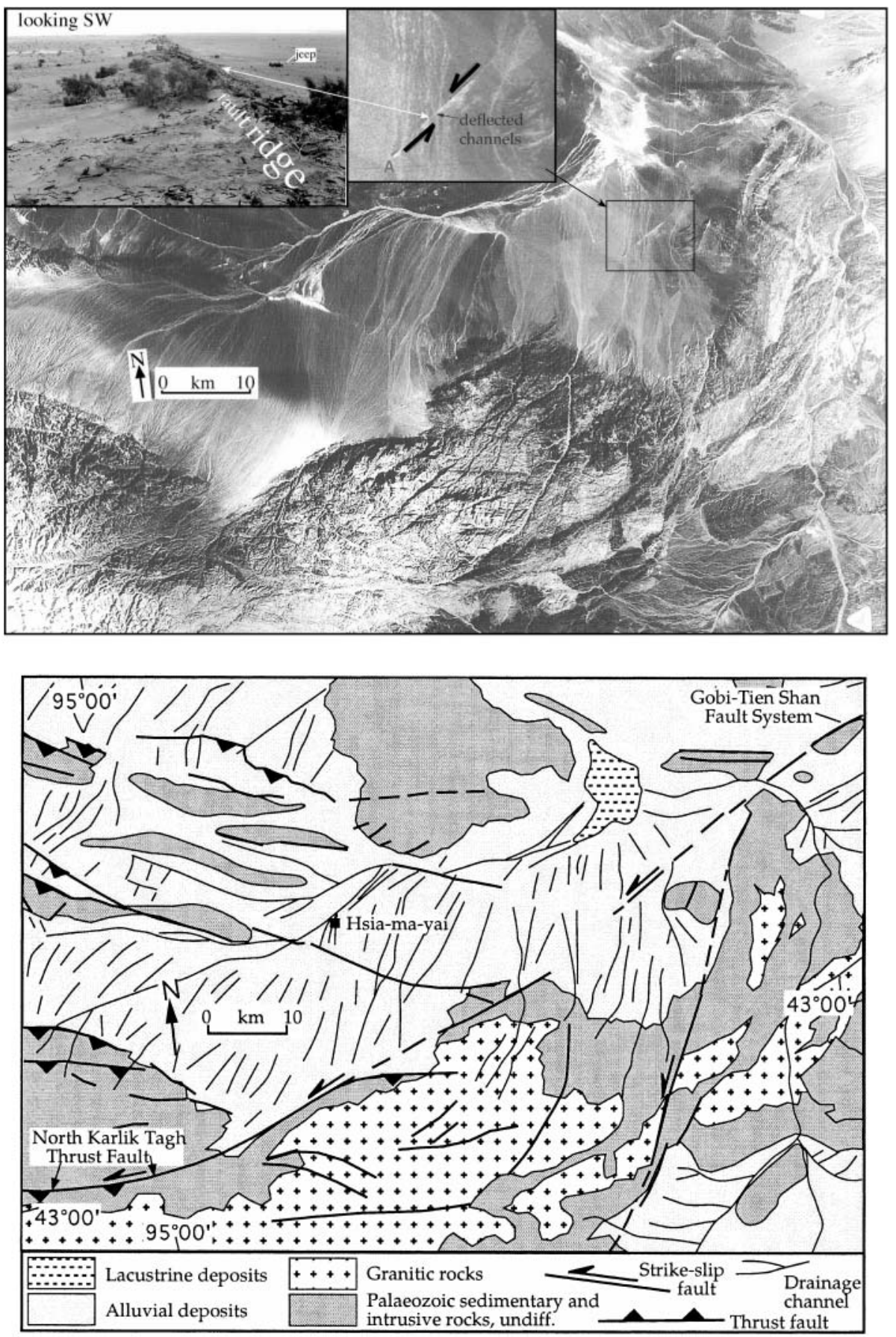

Fig. 12. (a) Landsat image of eastern end of Tien Shan east of Karlik Tagh near China-Mongolia border. (See Fig. 1 for location.) The eastern continuation of North Karlik Tagh Thrust Fault should be noted; this curves gently towards the NE, where decreasing elevations adjacent to the fault suggest that it accommodates less thrust motion and greater strike-slip motion. Also noteworthy is the NE continuation of North Karlik Tagh Thrust Fault where it cuts basin fill material east of Hsia-ma-yai. Inset photographs show left-lateral offsets of dry stream channels (arrow) and SW groundlevel view of fault zone. (b) Geological interpretation of (a) showing major faults in the region. Faults at eastern end of Karlik Tagh connect with strike-slip faults further east in SW Mongolia and constitute the western end of the Gobi-Tien Shan leftlateral strike-slip fault system that runs for $400 \mathrm{~km}$ and structurally links the easternmost Tien Shan with ranges in the southern Gobi Altai region of Mongolia (Fig. 1; see Cunningham et al. 1996a). depth. The thickness of Cenozoic alluvial fill that is overthrust at the South Karlik Tagh front is poorly constrained, and thus the amount of shortening on that bounding fault is a minimum estimate. The amount of Cenozoic shortening across the small Adak ridge (Fig. 10) is not defined by offset peneplain surfaces, but is likely to be only a few kilometres at best because of the low elevation and narrow width of the ridge. Thus a conservative estimate is that only $10-15 \mathrm{~km}$ of Cenozoic shortening were required to construct the modern easternmost Tien Shan.

The Ar-Ar data indicate that the north bounding thrust faults for Karlik and Barkol Tagh are older latest Permian-early
Triassic ductile thrust faults that underwent brittle reactivation as Late Cenozoic thrusts. Permian-Triassic thrusting and consequent topographic uplift in the easternmost Tien Shan are also indicated by sedimentological data in the Junggar and TurpanHami basins, which suggest that physical separation of these basins began at that time (Hendrix 2000; Greene et al. 2001). Ductile thrusting on the major thrust fault that bounds the southern front of Karlik Tagh also occurred during the Triassic, presumably during a continuation of the same major contractional event recorded on the north sides of Barkol and Karlik Tagh. This contractional event is regionally characterized by 


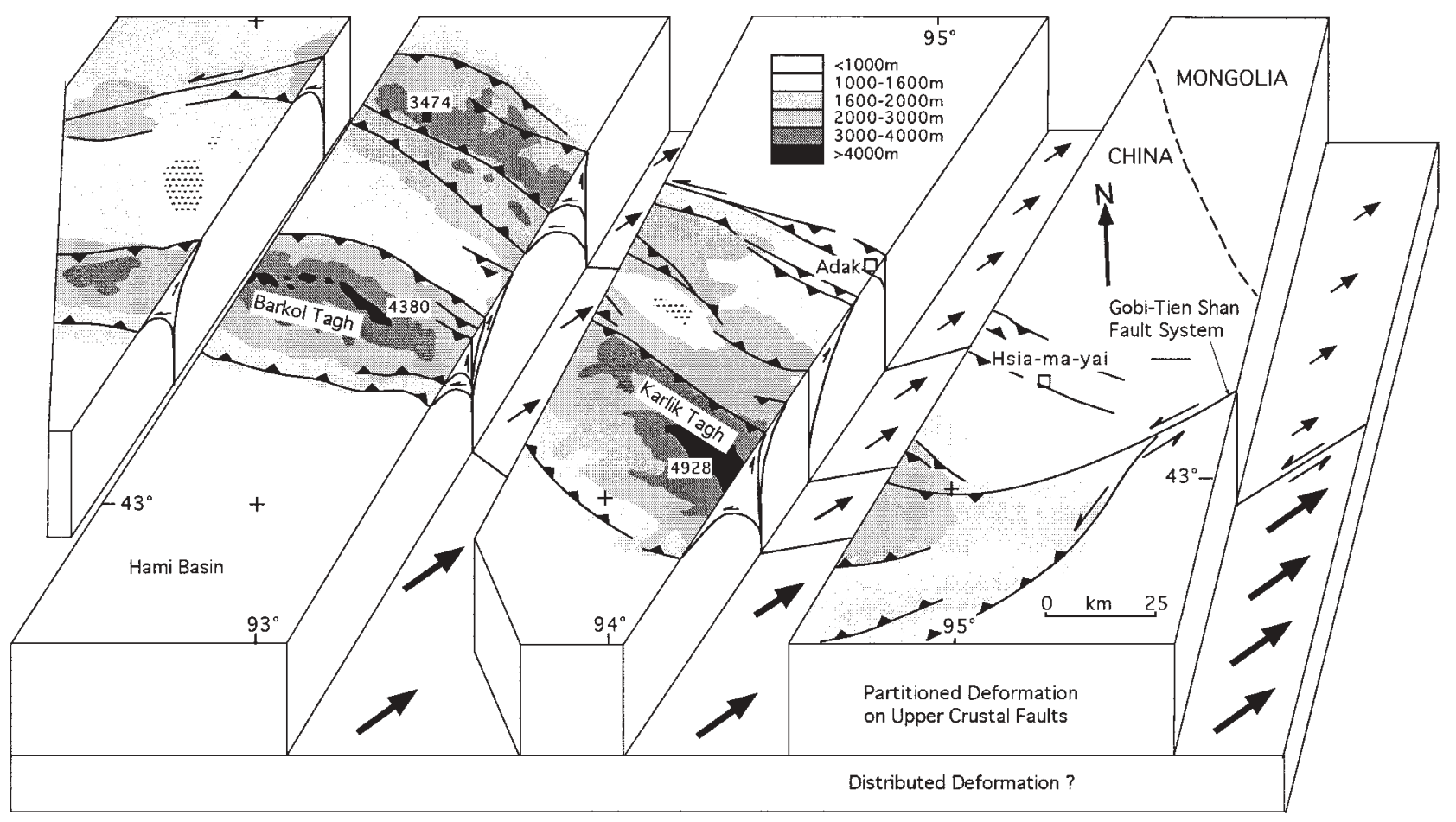

Fig. 13. Block diagram interpretation for easternmost Tien Shan in Barkol Tagh and Karlik Tagh regions, Xinjiang Province, western China. Fault interpretations are based on field observations documented in this study and Landsat interpretations of areas not visited. Interpretation of fault attitudes and linkage at depth is speculative, as is qualitative model for more distributed deformation in lower crust. Difference in arrow size schematically represents relative velocity contrasts inducing left-lateral northeastward shearing at eastern end of Karlik Tagh.

northward-propagating thrusting, presumably driven by terrane accretion events along the south Asian margin and perhaps final consolidation of arc terranes in the Tien Shan and Junggar Basin regions (Hendrix 2000; Greene et al. 2001). A later pulse of Jurassic tectonism and uplift is also indicated by sedimentological and fission-track data in the Bogda Shan region and suggested by the $\mathrm{Ar}-\mathrm{Ar}$ data for the north and south Karlik Tagh thrust faults, which suggest partial resetting around $160 \mathrm{Ma}$ (Fig. 6). Thus uplift and exhumation of metamorphic basement rocks and ductile thrust fabrics in Karlik Tagh are a combination of Mesozoic and Cenozoic thrusting and erosion.

From a Mongolian perspective, Karlik Tagh and nearby ranges to the north occupy a restraining bend position with respect to the left-lateral Gobi-Tien Shan Fault System (Fig. 1). The broad sigmoidal shape of Karlik and Barkol Tagh is typical of restraining bend uplifts (Fig. 1). Faults in the Karlik Tagh region grossly define a horsetail splay geometry (Fig. 13; Biddle \& Christie-Blick 1985) although it is not clear how the faults converge and link east of Karlik Tagh, where topography is subdued and alluvium obscures fault traces (Figs 12 and 13). Unpublished aeromagnetic data suggest a minimum of 40$60 \mathrm{~km}$ of left-lateral offset along the Gobi-Tien Shan Fault System in SW Mongolia (Cunningham 1998). Thrust displacements and possibly block rotations in Barkol and Karlik Tagh and in lesser ranges in SW Mongolia during combined Mesozoic and Cenozoic deformation events must have accommodated this motion.

From a central Tien Shan perspective, the easternmost Tien Shan represents a continuation of thrust-related uplift as seen further west (e.g. Allen et al. 1993a, b, Allen et al. 1994) but with a gradually increasing strike-slip component towards the east that evolves into an overall left-lateral transpressional regime and finally pure strike-slip deformation at the Mongolian border. From this central Tien Shan view, the Gobi-Tien Shan Fault System represents a transform type fault that transfers NEdirected compressive stresses to isolated ranges of the SE Gobi Altai in southern Mongolia, $400 \mathrm{~km}$ further east (Fig. 1), where late Cenozoic thrusting and left-lateral transpressional deformation have occurred (Cunningham et al. 1996a). Thus from a structural perspective, the easternmost Tien Shan is linked to the southern Gobi Altai and these Mongolian ranges represent oblique left-lateral transpressional east-northeastward propagation of the Tien Shan. Thus, depending on the way in which NEdirected maximum compressive stress is partitioned between thrusting and left-lateral strike-slip displacements, and whether thrusting displacement rates exceed ambient erosion rates, the Tien Shan may eventually propagate and link eastwards into a topographically continuous range in SW Mongolia.

The reason that the Tien Shan becomes increasingly transpressional towards its eastern extremity is presumably the angular relationship between a gradually changing stress field (from north-south maximum compressive stress in the west to NESW in the east; Tapponnier \& Molnar 1979; Zoback 1992) and pre-existing basement structural grain that changes from NWSE in the central Tien Shan to more east-west in the easternmost Tien Shan (Geological Map of Xinjiang Province, Chen 1983). Where the maximum horizontal stress impinges on basement grain at high angles, thrusting dominates as in the central Tien Shan, whereas where it impinges on basement structural grain at more acute angles, as in the easternmost Tien Shan, ENE-striking 


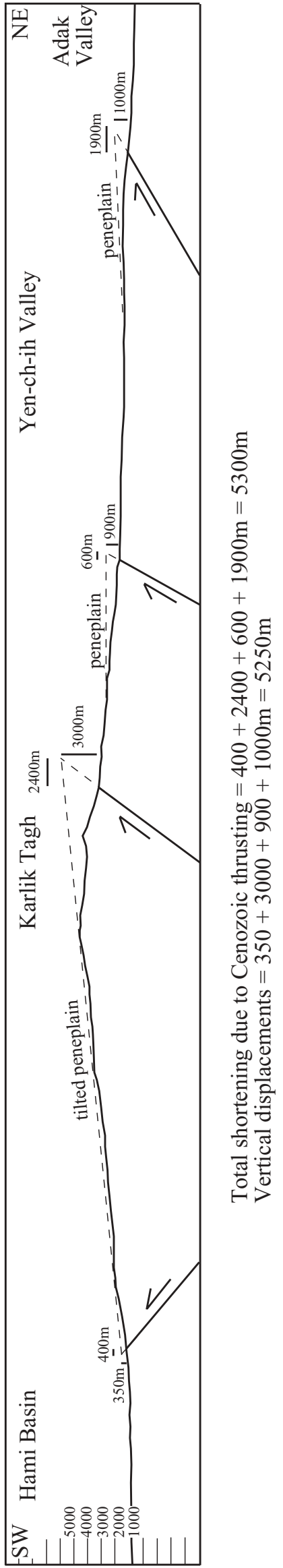

strike-slip faults and oblique-slip thrusts accommodate some of the NE-directed motion.

Special thanks go to Yitian Wang and Lianjun Yu for their help in the field and warm friendship. Reviews by Mark Allen, Peter Cobbold and Peter Cawood were helpful and led to improvements in the manuscript. This work was supported by NERC grant GR9/01881 awarded to L.A.O. and B. Windley. We thank British Petroleum for providing the Landsat imagery.

\section{References}

Abdrakhmatov, K.Y. \& Aldazhanov, S.A. ET AL. 1996. Relatively recent construction of the Tien Shan inferred from GPS measurements of presentday crustal deformation rates. Nature, 384, 450-453.

Allen, M.B., Windley, B.F., Zhang, C., ZhaO, Z.-Y. \& Wang, G.-R. 1991 Basin evolution within and adjacent to the Tien Shan Range, NW China. Journal of the Geological Society, London, 148, 369-378.

Allen, M.B., Windley, B.F. \& Zhang, C. 1993a. Palaeozoic collisional tectonics and magmatism of the Chinese Tien Shan, central Asia. Tectonophysics, 220, $89-115$.

Allen, M.B., Windley, B.F., Zhang, C. \& Guo, J. 1993b. Evolution of the Turfan basin, Chinese Central Asia. Tectonics, 12(4), 889-896.

Allen, M.B., Windley, B.F. \& Zhang, C. 1994. Cenozoic tectonics in the Urumqi-Korla region of the Chinese Tien Shan. Geologische Rundschau, 83 , $1156-1168$.

Allen, M.B., Vincent, S.J. \& Wheeler, P. 1999. Late Cenozoic tectonics of the Kepingtage thrust zone: interactions of the Tien Shan and Tarim Basin, northwest China. Tectonics, 18(4), 639-654.

Avouac, J.P. \& TAPPONniER, P. 1993. Kinematic model of active deformation in central Asia. Geophysical Research Letters, 20(10), 895-898.

Avouac, J.P., Tapponnier, P., Bai, M., You, H. \& Wang, G. 1993. Active thrusting and folding along the northern Tien Shan and late Cenozoic rotation of the Tarim relative to Dzungaria and Kazakhstan. Journal of Geophysical Research, 98(B4), 6755-6804.

Biddle, K.T. \& Christie-Blick, N. 1985. Glossary—strike-slip deformation, basin formation and sedimentation. In: Biddle, K.T. \& Christie-Blick, N. (eds) Strike-slip Deformation, Basin Formation and Sedimentation. SEPM Special Publications, 37, 375-384.

BurchFiel, B.C. \& Brown, E.T. ET AL. 1999. Crustal shortening on the margins of the Tien Shan, Xinjiang, China. International Geology Review, 41, 665-700.

Burtman, V.S. 1975. Structural geology of the Variscan Tien Shan, USSR American Journal of Science, 272A, 157-186.

Chen, Z. (ed.) 1983. Geologic Map of Xinjiang Province, 1:2,000,000. Bureau of Geology and Mineral Resources of Xinjiang Uygur Autonomous Region.

Cobbold, P.R. \& Davy, P.H. 1988. Indentation tectonics in nature and experiment, 2. Central Asia. Bulletin of the Geological Institute University of Uppsala, N.S., 14, 143-162.

Cobbold, P.R., Sadybakasov, E. \& Thomas, J.C. 1996. Cenozoic transpression and basin development, Kyrghyz Tienshan, Central Asia. In: Roure, F., Ellouz, N., Shein, V.S. \& Skvortsov, I. (eds) Geodynamic Evolution of Sedimentary Basins. Technip, Paris, 181-202.

Cunningham, W.D. 1998. Lithospheric controls on Late Cenozoic construction of the Mongolian Altai. Tectonics, 17(6), 891-902.

Cunningham, W.D. 2000. Cenozoic normal faulting and regional doming in the southern Hangay region, Central Mongolia: implications for the origin of the Baikal Rift Province. Tectonophysics, 331(4), 389-411.

Cunningham, W.D., Windley, B.F., Dorjnamuaa, D., Badamgarov, G. \& SAANDAR, M. 1996a. Late Cenozoic transpression in southwestern Mongolia and the Gobi Altai-Tien Shan connection. Earth and Planetary Science Letters, 140(1-4), 67-82

Cunningham, W.D., Windley, B.F., DorjnamuaA, D., Badamgarov, G., SAANDAR, M. \& A,. 1996b. A structural transect across the Mongolian Altai: active transpressional mountain building in central Asia. Tectonics, 15(1), $142-156$.

Fig. 14. Block cross-section for Karlik Tagh from Hami Basin to the Adak valley. Minimum estimate of shortening is $5-6 \mathrm{~km}$ based on four separate thrust offsets of the Late Cretaceous-Palaeocene peneplain. Fault dips at surface are extrapolated to depth. Peneplains are projected above areas where they have been eroded. (See Fig. 2 for location of section.) 
Cunningham, W.D., Windley, B.F., Owen, L.A., Barry, T., DorjnamuaA, D., Badamgarav, G. \& SaAndar, M. 1997. Geometry and style of partitioned deformation within a late Cenozoic transpressional zone in the eastern Gobi Altai Mountains, Mongolia. Tectonophysics, 277, 285-306.

Dalrymple, G.B., Alexander, E.C.J., Lanphere, M.A. \& Kraker, G.P. 1981. Irradiation of Samples for ${ }^{40} \mathrm{Ar} /{ }^{39} \mathrm{Ar}$ Dating using the Geological Survey TRIGA Reactor. US Geological Survey, Professional Papers, 1176.

DevyatKin, E.V. 1974. Structures and formational complexes of the Cenozoic activated stage. In: EDITOR, A. (ed.) Tectonics of the Mongolian People's Republic. Nauka, Moscow, 182-195 [in Russian].

Dumitru, T.A., Zhou, D., Chang, E.Z., Graham, S.A., Hendrix, M.S., Sobel, E.R. \& Carroll, A.R. 2001. Uplift, exhumation and deformation in the Chinese Tian Shan. In: Hendrix, M.S. \& Davis, G.A. (eds) Paleozoic and Mesozoic Evolution of Central Asia: from Continental Assembly to Intracontinental Deformation. Geological Society of America, Memoirs, 194, 117-149.

Feng, X., Deng, Q., Shi, J., You, H., Zhang, Y., Yu, G. \& Wu, Z. 1991. Active tectonics of the southern and northern Tianshan and its tectonic evolution. In: Editor, A. (ed.) Research on Active Fault. Seismological Press, Beijing, 1, 1-16 [in Chinese].

FleCK, R.J., SutTER, J.F. \& Elliot, D.H. 1977. Interpretation of discordant ${ }^{40} \mathrm{Ar} /$ ${ }^{39} \mathrm{Ar}$ age-spectra of Mesozoic tholeiites from Antarctica. Geochimica et Cosmochimica Acta, 41, 15-32.

Greene, T.J., Carroll, A.R., Hendrix, M.S., Graham, S.A., Wartes, M.A. \& AвbinK, O.A. 2001. Sedimentary record of Mesozoic deformation and inception of the Turpan-Hami basin, northwest China. In: HENDRIX, M.S. \& Davis, G.A. (eds) Paleozoic and Mesozoic Evolution of Central Asia: from Continental Assembly to Intracontinental Deformation. Geological Society of America, Memoirs, 194, 117-149.

Hager, B. \& Herring, T. ET AL. 1996. Relatively recent construction of the Tien Shan inferred from GPS measurements of recent crustal deformation. EOS Transactions, American Geophysical Union, 77(46), 143-144.

HendRix, M.S. 2000. Evolution of Mesozoic sandstone compositions, southern Junggar, northern Tarim, and western Turpan basins, northwest China: a detrital record of the ancestral Tian Shan. Journal of Sedimentary Research, 70(3), 520-532.

Hendrix, M.S., Graham, S.A., Carroll, A.R., Sobel, E.R., McKnight, C.L., SchukeIN, B.J. \& WANG, Z. 1992. Sedimentary record and climatic implications of recurrent deformation in the Tian Shan: evidence from Mesozoic strata of the north Tarim, south Junggar, and Turpan basins, northwest China. Geological Society of America Bulletin, 104, 53-79.

Hendrix, M.S., Dumitru, T.A. \& Graham, S. 1994. Late Oligocene-early Miocene unroofing in the Chinese Tian Shan: an early effect of the IndiaAsia collision. Geology, 22, 487-490.

Hess, J.C. \& LiPPOLT, H.J. 1986. Kinetics of Ar isotopes during neutron irradiation: ${ }^{39} \mathrm{Ar}$ loss from minerals as a source of error in ${ }^{40} \mathrm{Ar} /{ }^{39} \mathrm{Ar}$ dating. Chemical Geology, 59, 223-236.

Hubert-Ferrari, A., Suppe, J., Wang, X., Lu, H., Li, Q.M. \& Jia, C.Z. 1999. $18 \mathrm{kyr}, 120 \mathrm{kyr} \& 5$ myr shortening rates along the front of the southern Tianshan mountains (China). Geological Society of America, Abstracts with Programs, 31(7), 376.

Khil'Ko, S.D., Kurushin, R.A., KochetKov, V.M., Baljinnyam, I. \& MonKoo, D. 1985. Earthquakes and the Bases for Seismic Zoning of Mongolia, Transactions 41, The Joint Soviet-Mongolian Scientific Geological Research Expedition. Nauka, Moscow.

Lamb, M.A. \& Badarch, G. 2001. Paleozoic sedimentary basins and volcanic arc systems of southern Mongolia: new geochemical and petrographic constraints. In: Hendrix, M.S. \& Davis, G.A. (eds) Paleozoic and Mesozoic Evolution of Central Asia: from Continental Assembly to Intracontinental Deformation. Geological Society of America, Memoirs, 194, 117-149.

Lo, C.H. \& OnstotT, T.C. $1989 .{ }^{39} \mathrm{Ar}$ recoil artifacts in chloritized biotite. Geochimica et Cosmochimica Acta, 53, 2697-2711.

McIntyre, D.B. 1963. Precision and resolution in geochronometry. In: Albritton, C.C. (ed.) The Fabric of Geology. Addison-Wesley, Reading, MA, 112-134.

Molnar, P. \& Deng, Q. 1984. Faulting associated with large earthquakes and the average rate of deformation in central and eastern Asia. Journal of Geophysical Research, 89, 6203-6227.

Molnar, P. \& GHose, S. 2000. Seismic moments of major earthquakes and the rate of shortening across the Tien Shan. Geophysical Research Letters,
27(16), 2377-2380

Molnar, P. \& Tapponnier, P. 1975. Cenozoic tectonics of Asia: effects of a continental collision. Science, 189(4201), 419-426.

Neil, E.A. \& Houseman, G.A. 1997. Geodynamics of the Tarim Basin and the Tian Shan in central Asia. Tectonics, 16(4), 571-584.

Nelson, M.R., McCafferey, R. \& Molnar, P. 1987. Source parameters for eleven earthquakes in the Tien Shan, Central Asia, determined by $\mathrm{P}$ and $\mathrm{SH}$ waveform inversion. Journal of Geophysical Research, 92, 12629-12648.

NI, J. 1978. Contemporary tectonics in the Tien Shan region. Earth and Planetary Science Letters, 41, 347-354.

Peng, X. \& Zhang, G. 1989. Tectonic features of the Junggar basin and their relationship with oil and gas distribution. In: ZHU, X. (ed.) Chinese Sedimentary Basins. Elsevier, Amsterdam, 17-31.

Regional Survey Team, Xinjiang Geological Bureau 1966a. Geologic Map of Hami, 1: 200,000.

Regional Survey Team, Xinjiang Geological Bureau 1966b. Geologic Map of $I-w u, 1: 200,000$

Regional Survey Team, Xinjiang Geological Bureau 1966c. Geologic Map of Laomaohu, 1: 200,000.

Regional Survey Team, Xinjiang Geological Bureau 1966d. Geologic Map of Pa-li-k'un, 1: 200,000.

RoDDICK, J.S. 1983. High-precision intercalibration of ${ }^{40} \mathrm{Ar} /{ }^{39} \mathrm{Ar}$ standards. Geochimica et Cosmochimica Acta, 47, 887-898.

Samson, S.D. \& AleXANDER, E.C.J. 1987. Calibration of interlaboratory ${ }^{40} \mathrm{Ar} /{ }^{39} \mathrm{Ar}$ dating standard MMhb-1. Chemical Geology, 66, 27-43.

SEARLE, M.P. 1996. Geological evidence against large-scale pre-Holocene offsets along the Karakorum Fault: implications for the limited extrusion of the Tibetan plateau. Tectonics, 15, 171-186.

SNEE, L.W. 2003. Argon thermochronology of mineral deposits-a review. US Geological Survey Bulletin, in press.

Sobel, E.R. \& Dumitru, T.A. 1997. Thrusting and exhumation around the margins of the western Tarim basin during the Indo-Eurasia collision. Journal of Geophysical Research, 102, 5043-5063.

Staudacher, Th., Jessburger, E.K., Dorflinger, D. \& Kiko, J. 1978. A refined ultrahigh-vacuum furnace for rare-gas analysis. Journal of Physics E, Scientific Instruments, 11, 781-784.

Steiger, R.H. \& JäGER, E. 1977. Subcommission on geochronology: convention on the use of decay constants in geo- and cosmochronology. Earth and Planetary Science Letters, 36, 359-362.

TApponnier, P. \& Molnar, P. 1979. Active faulting and Cenozoic tectonics of the Tien Shan, Mongolia, and Baykal regions. Journal of Geophysical Research, 84, 3425-3459.

Tapponnier, P., Peltzer, G., Le Dain, A.Y., Armijo, R. \& Cobbold, P. 1982. Propagating extrusion tectonics in Asia: new insights from simple experiments with plasticine. Geology, 10, 611-616.

Wang, Q. \& Zhang, P.-Z. ET AL. 2001. Present-day crustal deformation in China constrained by global positioning system measurements. Science, 294, $574-577$

Westaway, R. 1995. Crustal volume balance during the India-Eurasia collision and altitude of the Tibetan Plateau: a working hypothesis. Journal of Geophysical Research, 100, 15173-15192.

Windley, B.F., Allen, M.B., Zhang, C., Zhao, Z.-Y. \& Wang, G.-R. 1990 Paleozoic accretion and Cenozoic redeformation of the Chinese Tien Shan Range, central Asia. Geology, 18, 128-131.

Yin, A., Nie, S., Craig, P., Harrison, T.M., Ryerson, F.J., Xianglin, Q. \& GeNG, Y. 1998. Late Cenozoic tectonic evolution of the southern Chinese Tien Shan. Tectonics, 17(1), 1-27.

YoRK, D. 1969. Least squares fitting of a straight line with correlated errors. Earth and Planetary Science Letters, 5, 320-344

Zhou, D., Graham, S.A., Chang, E.Z., Wang, B. \& Hacker, B. 2001. Paleozoic tectonic amalgamation of the Chinese Tian Shan: evidence from a transect along the Dushanzi-Kuqa Highway. In: Hendrix, M.S. \& Davis, G.A. (eds) Paleozoic and Mesozoic Evolution of Central Asia: from Continental Assembly to Intracontinental Deformation. Geological Society of America, Memoirs, 194, 23-46.

Zoback, M.L. 1992. First- and second-order patterns of stress in the lithosphere: the world stress map project. Journal of Geophysical Research, 97(B8), $11703-11728$. 


\section{APPENDIX}

${ }^{40} \mathrm{Ar} /{ }^{39} \mathrm{Ar}$ data are shown in Table 1.

Table 1. ${ }^{40} \mathrm{Ar}{ }^{39} \mathrm{Ar}$ data for samples from deformed rocks in the easternmost Tien Shan, China

\begin{tabular}{|c|c|c|c|c|c|c|c|}
\hline$T\left({ }^{\circ} \mathrm{C}\right)$ & Radiogenic ${ }^{40} \mathrm{Ar}^{*}$ & $\mathrm{~K}$-derived ${ }^{39} \mathrm{Ar}^{*}$ & ${ }^{40} \mathrm{Ar}_{\mathrm{R}} /{ }^{\beta 9} \mathrm{Ar}_{\mathrm{K}}^{\dagger}$ & ${ }^{39} \mathrm{Ar}_{\mathrm{K}}{ }^{\beta 7} \mathrm{Ar}_{\mathrm{Ca}}{ }^{*}$ & Radiogenic yield & ${ }^{39} \mathrm{Ar}_{\mathrm{K}}(\%)$ & $\begin{array}{l}\text { Apparent age and } \\
\text { error }^{\S} \text { (Ma) }\end{array}$ \\
\hline \multicolumn{8}{|c|}{$B T 1$, white mica } \\
\hline 500 & 0.0496 & 0.0034 & 14.50 & 330 & 4.7 & 0.3 & $96 \pm 2$ \\
\hline 600 & 1.4713 & 0.04385 & 33.551 & 109 & 63.6 & 3.9 & $215.0 \pm 0.4$ \\
\hline 700 & 5.5525 & 0.15585 & 33.627 & 135 & 98.2 & 13.8 & $227.5 \pm 0.7$ \\
\hline 750 & 8.2431 & 0.21005 & 39.243 & 200 & 99.7 & 18.6 & $249.1 \pm 0.4$ \\
\hline 800 & 8.6784 & 0.22172 & 39.141 & 265 & 99.8 & 19.6 & $248.5 \pm 0.4$ \\
\hline 850 & 5.6008 & 0.14408 & 38.871 & 180 & 99.7 & 12.7 & $246.9 \pm 0.4$ \\
\hline 900 & 5.0761 & 0.12976 & 39.120 & 267 & 99.7 & 11.5 & $248.4 \pm 0.4$ \\
\hline 950 & 4.0697 & 0.10248 & 39.712 & 190 & 99.6 & 9.1 & $251.9 \pm 0.4$ \\
\hline 1050 & 2.8264 & 0.06983 & 40.474 & 180 & 99.5 & 6.2 & $256.4 \pm 0.4$ \\
\hline 1150 & 1.8174 & 0.04506 & 40.331 & 104 & 99.4 & 4.0 & $255.5 \pm 0.6$ \\
\hline 1250 & 0.2103 & 0.0054 & 38.94 & 18 & 98.4 & 0.5 & $247 \pm 8$ \\
\hline \multicolumn{8}{|c|}{$K T 1$, white mica } \\
\hline 500 & 0.30147 & 0.0121 & 24.92 & 52 & 69.6 & 3.6 & $162.6 \pm 0.6$ \\
\hline 600 & 0.2790 & 0.0094 & 29.70 & 58 & 98.2 & 2.8 & $192.2 \pm 1.5$ \\
\hline 700 & 1.2431 & 0.03852 & 32.275 & 76 & 97.8 & 11.4 & $207.9 \pm 0.8$ \\
\hline 750 & 1.2633 & 0.03634 & 34.761 & 107 & 99.2 & 10.8 & $223.0 \pm 0.8$ \\
\hline 800 & 1.6160 & 0.04468 & 36.169 & 108 & 99.7 & 13.3 & $231.5 \pm 0.8$ \\
\hline 850 & 1.8708 & 0.05037 & 37.140 & 163 & 99.2 & 14.9 & $237.3 \pm 0.4$ \\
\hline 900 & 1.6501 & 0.04310 & 38.285 & 140 & 99.6 & 12.8 & $244.1 \pm 0.6$ \\
\hline 950 & 1.3703 & 0.03498 & 39.177 & 78 & 99.7 & 10.4 & $249.4 \pm 0.5$ \\
\hline 1000 & 1.3185 & 0.03342 & 39.457 & 53 & 99.3 & 9.9 & $251.1 \pm 0.4$ \\
\hline 1050 & 0.46363 & 0.0121 & 38.20 & 25 & 98.0 & 3.6 & $243.6 \pm 1.0$ \\
\hline 1150 & 0.38418 & 0.0110 & 34.99 & 13 & 97.6 & 3.3 & $224.3 \pm 2.4$ \\
\hline 1250 & 0.32696 & 0.0110 & 29.87 & 11 & 97.2 & 3.2 & $193.2 \pm 2.2$ \\
\hline \multicolumn{8}{|c|}{ KT1, K-feldpar } \\
\hline 650 & 0.49042 & 0.01952 & 25.13 & 316 & 77.5 & 6.9 & $162.8 \pm 0.4$ \\
\hline 850 & 1.5066 & 0.05562 & 27.09 & 491 & 97.7 & 19.6 & $175.9 \pm 0.6$ \\
\hline 1050 & 1.0669 & 0.0387 & 27.56 & 133 & 97.9 & 13.6 & $177.8 \pm 1.4$ \\
\hline 1250 & 2.5163 & 0.09027 & 27.88 & 209 & 98.2 & 31.8 & $179.7 \pm 0.3$ \\
\hline 1400 & 2.2783 & 0.07972 & 28.58 & 601 & 97.3 & 28.1 & $184.0 \pm 0.3$ \\
\hline \multicolumn{8}{|c|}{$K T 2$, white mica } \\
\hline 500 & 0.0876 & 0.0059 & 14.80 & 2.77 & 41.3 & 1.0 & $98.6 \pm 1.6$ \\
\hline 600 & 0.70417 & 0.03010 & 23.39 & 2.91 & 87.6 & 4.9 & $153.4 \pm 0.3$ \\
\hline 700 & 1.7857 & 0.05350 & 33.38 & 4.46 & 97.0 & 8.7 & $215.1 \pm 0.3$ \\
\hline 750 & 2.7450 & 0.07636 & 35.95 & 7.24 & 97.4 & 12.5 & $230.7 \pm 0.3$ \\
\hline 800 & 2.2736 & 0.06296 & 36.11 & 8.90 & 97.3 & 10.3 & $231.7 \pm 0.5$ \\
\hline 850 & 2.2249 & 0.06053 & 36.76 & 3.22 & 98.2 & 9.9 & $235.6 \pm 0.3$ \\
\hline 900 & 2.7000 & 0.07364 & 36.67 & 3.21 & 99.0 & 12.0 & $235.0 \pm 0.3$ \\
\hline 1000 & 6.4553 & 0.17697 & 36.48 & 1.62 & 99.2 & 28.9 & $233.9 \pm 0.3$ \\
\hline 1050 & 1.5202 & 0.04245 & 35.81 & 0.70 & 98.9 & 6.9 & $229.9 \pm 0.3$ \\
\hline 1100 & 0.62332 & 0.01889 & 32.99 & 0.52 & 96.0 & 3.1 & $212.8 \pm 0.6$ \\
\hline 1200 & 0.3414 & 0.0114 & 29.99 & 0.07 & 92.7 & 1.9 & $194.4 \pm 1.4$ \\
\hline \multicolumn{8}{|c|}{$K T 2, K$-feldspar } \\
\hline 500 & 0.0115 & 0.0018 & 6.530 & 37 & 7.7 & 0.4 & $44 \pm 13$ \\
\hline 600 & 0.64945 & 0.0272 & 23.92 & 35 & 90.9 & 6.6 & $155.8 \pm 2.0$ \\
\hline 700 & 0.73184 & 0.02831 & 25.85 & 32 & 94.4 & 6.9 & $167.8 \pm 0.2$ \\
\hline 800 & 2.0451 & 0.06841 & 29.90 & 35 & 97.5 & 16.7 & $192.7 \pm 0.5$ \\
\hline 900 & 1.7968 & 0.05700 & 31.52 & 22 & 97.7 & 13.9 & $202.6 \pm 0.6$ \\
\hline 950 & 0.60642 & 0.01963 & 30.89 & 18 & 95.2 & 4.8 & $198.8 \pm 0.5$ \\
\hline 1050 & 1.2909 & 0.0415 & 31.12 & 17 & 96.8 & 10.1 & $200.2 \pm 1.5$ \\
\hline 1100 & 0.80951 & 0.02655 & 30.49 & 15 & 96.3 & 6.5 & $196.3 \pm 0.3$ \\
\hline 1150 & 0.5862 & 0.0191 & 30.70 & 14 & 97.0 & 4.7 & $197.6 \pm 1.5$ \\
\hline 1200 & 1.4448 & 0.04729 & 30.55 & 13 & 96.7 & 11.5 & $196.7 \pm 0.5$ \\
\hline 1250 & 2.2708 & 0.07309 & 31.07 & 23 & 96.9 & 17.8 & $199.9 \pm 0.3$ \\
\hline
\end{tabular}

BT1, Barkol Tagh, mylonitized quartz-muscovite schist, white mica: total-gas date $244.9 \pm 0.5 \mathrm{Ma}$; no plateau; $J=0.003773$, $\pm 0.1 \%$; weight 55.6 mg. KT1, Karlik Tagh, mylonitized quartzite, white mica: total-gas date $229.7 \pm 0.8 \mathrm{Ma}$; no plateau; $J=0.003785, \pm 0.1 \%$; weight $44.2 \mathrm{mg}$. KT1, Karlik Tagh, mylonitized quartzite, potassium feldspar: total-gas date $176.6 \pm 0.5 \mathrm{Ma}$; no plateau; $J=0.003758, \pm 0.1 \%$; weight $9.4 \mathrm{mg}$. KT2, Karlik Tagh, mylonitized granite, white mica: total-gas date $225.2 \pm 0.4 \mathrm{Ma}$; no plateau; $J=0.003795, \pm 0.1 \%$; weight $45.1 \mathrm{mg}$. KT2, Karlik Tagh, mylonitized granite, potassium feldspar: total-gas date $192.6 \pm 0.9 \mathrm{Ma}$; no plateau; $J=0.003771$, $\pm 0.1 \%$; weight $34.6 \mathrm{mg}$. Mineral concentrates were derived from rock samples that were crushed, ground and sieved to $60-120$ mesh size ( $250-125 \mu \mathrm{m})$. Concentrates were passed through magnetic separator and heavy liquids and then handpicked to maximum purity. Because samples were mylonitic, minerals were fine grained and commonly composited. Pure concentrates could not be separated. White mica concentrates included variable amounts of chlorite and quartz; potassium feldspar concentrates included some quartz. All concentrates were cleaned with reagent-grade acetone, alcohol and deionized water, and air-dried in an oven at $75^{\circ} \mathrm{C}$. Between 9 and 56 mg of concentrate were wrapped in aluminium foil packages and encapsulated in silica vials adjacent to neutron-fluence standards before irradiation. The standards for this experiment are hornblende MMhb-1 with $\mathrm{K} 1.555 \%,{ }^{40} \mathrm{Ar}_{\mathrm{R}} 1.624 \times 10^{-9} \mathrm{~mol} \mathrm{~g}^{-1}$ and $\mathrm{K}-\mathrm{Ar}$ age $520.4 \mathrm{Ma}$ (Samson \& Alexander 1987), and FCT sanidine with an internally calibrated age of 
27.84 Ma as measured against MMhb-1. For irradiation, an aluminium canister was loaded with six silica vials, each containing samples and standards similar to that described by Snee (2003). Standards were placed between every two samples as well as at the top and bottom of each silica vial. Samples were irradiated in one of three different irradiation packages in the TRIGA reactor at the US Geological Survey in Denver, Colorado. Length of irradiation was $20 \mathrm{~h}$ at $1 \mathrm{MW}$. The irradiation package was rotated at $1 \mathrm{rev} \mathrm{min}^{-1}$ during irradiation. All samples and standards were analysed in the Denver Argon Laboratory of the US Geological Survey using a Mass Analyser Products 215 rare-gas mass spectrometer on a Faraday-cup collector. Each sample was heated in a double-vacuum low-blank resistance furnace (similar to that described by Staudacher et al. 1978 ) for $20 \mathrm{~min}$, in a series of 5-12 steps, to a maximum of $1400{ }^{\circ} \mathrm{C}$, and analysed using the standard stepwise heating technique described by Snee (2003). Each standard was degassed to release argon in a single step at $1250{ }^{\circ} \mathrm{C}$ for MMhb-1, hornblende or at $1350{ }^{\circ} \mathrm{C}$ for FCT sanidine. For every argon measurement, five isotopes of argon $\left({ }^{40} \mathrm{Ar}\right.$, ${ }^{39} \mathrm{Ar},{ }^{38} \mathrm{Ar},{ }^{37} \mathrm{Ar}$ and ${ }^{36} \mathrm{Ar}$ ) were measured. Detection limit at the time of these experiments was $2 \times 10^{-17}$ moles of argon. Standard techniques were employed to produce ${ }^{40} \mathrm{Ar} /$ ${ }^{39} \mathrm{Ar}$ age spectra, apparent $\mathrm{K} / \mathrm{Ca}$ diagrams and isochron diagrams as described by Snee (2003).

* Abundance of 'radiogenic ${ }^{40} \mathrm{Ar}$ ' and 'K-derived ${ }^{39} \mathrm{Ar}$ ' is measured in volts and calculated to five decimal places. Voltage may be converted to moles using $1.160 \times 10^{-12}$ moles argon per volt signal. ' ${ }^{40} \mathrm{Ar}_{\mathrm{R}}{ }^{39} \mathrm{Ar}_{\mathrm{K}}$ ' is calculated to three decimal places. All three are rounded to significant figures using analytical precision.

${ }^{\dagger}{ }^{40} \mathrm{Ar}_{\mathrm{R}}{ }^{39} \mathrm{Ar}_{\mathrm{K}}$ ' has been corrected for mass discrimination. Mass discrimination was determined by calculating the ${ }^{40} \mathrm{Ar} /{ }^{36} \mathrm{Ar}$ ratio of aliquots of atmospheric argon pipetted from a fixed pipette on the extraction line; the ratio during these experiment was between 296.6 and 299.1, which was corrected to 295.5 to account for mass discrimination. ${ }^{40} \mathrm{Ar}_{\mathrm{R}} /{ }^{39} \mathrm{Ar}_{\mathrm{K}}$ ' was corrected for all interfering isotopes of argon including atmospheric argon. ${ }^{37} \mathrm{Ar}$ and ${ }^{39} \mathrm{Ar}$, which are produced during irradiation, are radioactive and their abundances were corrected for radioactive decay. Abundances of interfering isotopes from $\mathrm{K}$ and $\mathrm{Ca}$ were calculated from reactor production ratios determined by irradiating and analysing pure $\mathrm{CaF}_{2}$ and $\mathrm{K}_{2} \mathrm{SO}_{4}$; the $\mathrm{K}_{2} \mathrm{SO}_{4}$ was degassed in a vacuum furnace before irradiation to release extraneous argon. Corrections for Cl-derived ${ }^{36} \mathrm{Ar}$ were determined using the method of Roddick (1983). Production ratios for this experiment were determined $\left({ }^{40} \mathrm{Ar} /{ }^{39} \mathrm{Ar}\right)_{\mathrm{K}},\left({ }^{38} \mathrm{Ar} /{ }^{39} \mathrm{Ar}\right)_{\mathrm{K}},\left({ }^{37} \mathrm{Ar} /{ }^{39} \mathrm{Ar}\right)_{\mathrm{K}},\left({ }^{36} \mathrm{Ar} /{ }^{37} \mathrm{Ar}\right)_{\mathrm{Ca}},\left({ }^{39} \mathrm{Ar} /{ }^{37} \mathrm{Ar}\right)_{\mathrm{Ca}}$ and $\left({ }^{38} \mathrm{Ar}{ }^{37} \mathrm{Ar}\right)_{\mathrm{Ca}}$; measured values are available upon request.

"To calculate apparent $\mathrm{K} / \mathrm{Ca}$ ratios, the ${ }^{39} \mathrm{Ar}_{\mathrm{K}}{ }^{\beta 7} \mathrm{Ar}_{\mathrm{Ca}}$ ' value is divided by two. The accuracy of apparent $\mathrm{K} / \mathrm{Ca}$ ratios is dependent upon fast to thermal neutron ratios in the particular reactor. In the US Geological Survey TRIGA reactor the correction factor has not been determined since the study by Dalrymple et al. (1981). Because reactor fuel in the USGS TRIGA has been changed since 1981, this ratio must be viewed as approximate but is internally consistent for each sample and reveals within-sample variability. ${ }^{\S}$ Apparent ages and associated errors were calculated from unrounded analytical data then rounded using associated analytical errors. Apparent ages of each fraction include the error in $J$ value $(0.1 \%)$, which was calculated from the reproducibility of splits of the argon from several standards. Apparent ages were calculated using decay constants of

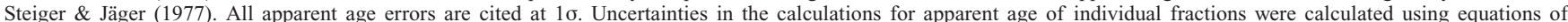
Dalrymple et al. (1981) and the critical value test of McIntyre (1963). Isochron analysis followed the procedures of York (1969).

Received 13 September 2002; revised typescript accepted 19 December 2002. Scientific editing by Alex Maltman 